NBER WORKING PAPER SERIES

\title{
MORAL INCENTIVES IN CREDIT CARD DEBT REPAYMENT: EVIDENCE FROM A FIELD EXPERIMENT
}

\author{
Leonardo Bursztyn \\ Stefano Fiorin \\ Daniel Gottlieb \\ Martin Kanz \\ Working Paper 21611 \\ http://www.nber.org/papers/w21611 \\ NATIONAL BUREAU OF ECONOMIC RESEARCH \\ 1050 Massachusetts Avenue \\ Cambridge, MA 02138
}

October 2015, Revised November 2017

\begin{abstract}
Previously circulated as "Moral Incentives: Experimental Evidence from Repayments of an Islamic Credit Card." We would like to thank Emily Breza, Michael Callen, Davide Cantoni, Eric Chaney, Shawn Cole, Ernesto Dal Bó, Stefano DellaVigna, Ruben Enikolopov, Ben Esty, Nicola Gennaioli, Xavier Giné, Paola Giuliano, Raji Jayaraman, Emir Kamenica, Asim Khwaja, Andrés Liberman, Adrien Matray, David McKenzie, Maria Petrova, Gautam Rao, Andrei Shleifer, Nico Voigtländer, RomainWacziarg, IvoWelch, Noam Yuchtman, and numerous seminar participants for helpful comments and suggestions. We are grateful to the UCLA Anderson Center for Global Management, the UCLA Anderson Price Center, and the World Bank for financial support. This study was approved by the UCLA and Washington University Institutional Review Boards, and registered in the American Economic Association Registry for randomized control trials under trial number AEARCTR-0000635. An earlier version of the paper was circulated under the title "Moral Incentives: Experimental Evidence from Repayments of an Islamic Credit Card." The opinions expressed in this paper do not necessarily represent the views of the World Bank, its Executive Directors, the countries they represent, or the National Bureau of Economic Research.
\end{abstract}

NBER working papers are circulated for discussion and comment purposes. They have not been peer-reviewed or been subject to the review by the NBER Board of Directors that accompanies official NBER publications.

(C) 2015 by Leonardo Bursztyn, Stefano Fiorin, Daniel Gottlieb, and Martin Kanz. All rights reserved. Short sections of text, not to exceed two paragraphs, may be quoted without explicit permission provided that full credit, including $\odot$ notice, is given to the source. 
Moral Incentives in Credit Card Debt Repayment: Evidence from a Field Experiment Leonardo Bursztyn, Stefano Fiorin, Daniel Gottlieb, and Martin Kanz

NBER Working Paper No. 21611

October 2015, Revised November 2017

JEL No. D14,G02,G21,Z10,Z12

\section{ABSTRACT}

We study the role of morality in debt repayment, using an experiment with the credit card customers of a large Islamic bank in Indonesia. In our main treatment, clients receive a text message stating that "non-repayment of debts by someone who is able to repay is an injustice." This moral appeal decreases the share of delinquent customers by 4.4 percentage points from a baseline of 66 percent, and reduces default among the customers with the highest ex-ante credit risk. Additional treatments help benchmark the effects against those of direct financial incentives, understand the underlying mechanisms, and rule out competing explanations, such as reminder effects, priming religion, signaling the lender's commitment to debt collection, and provision of new information.

Leonardo Bursztyn

Department of Economics

University of Chicago

1126 E. 59th Street

Chicago, IL 60637

and NBER

bursztyn@uchicago.edu

Stefano Fiorin

University of California San Diego

Rady School of Management

Wells Fargo Hall, Room 4W122

9500 Gilman Drive, MC 0553

La Jolla, CA 92093-0553

sfiorin@ucsd.edu
Daniel Gottlieb

Olin Business School

Washington University in St. Louis

One Brookings Drive

St. Louis, MO 63130

dgottlieb@wustl.edu

Martin Kanz

The World Bank

1818 H Street NW

Washington, DC 20433

mkanz@worldbank.org 


\section{Introduction}

The ability to collect debts is one of the main pillars of any financial system. While economists have extensively examined the importance of screening, monitoring, and reputational considerations, little attention has been paid to the role of morality in establishing a norm of debt repayment. This is quite surprising, given that throughout history - from ancient philosophy to contemporary debates - questions of debt and debt repayment have often been closely associated with issues of morality. In Plato's Republic, for example, Socrates defines the meaning of justice as "telling the truth and repaying one's debts." ${ }^{1}$ More recently, a heated debate about the morality of defaulting on one's mortgage or student loan in times of economic distress has featured prominently in the news media. ${ }^{2}$ Issues of morality have also played an important role in the context of sovereign debt, for example in debates about defaults and bailouts in countries such as Argentina or Greece.

In this paper, we study the role of moral considerations in debt repayment, using a field experiment with the credit card customers of a large Islamic bank in Indonesia, the world's most populous Muslim country. Islamic banking is a large and rapidly growing industry in Indonesia and around the world, with more than 300 banks in over 75 countries and approximately US $\$ 1.5$ trillion in assets (World Bank, 2014) offering Sharia-compliant financial products. While Islamic banks typically offer the same range of consumer financial products that are also available at conventional banks, they often emphasize the ethical dimension of their business model, thus providing an environment in which communications with both financial and moral content are natural. ${ }^{3}$

We use this setting to conduct a series of experiments in which late-paying credit card customers receive messages alerting them to the moral consequences of non-repayment. The design of our experiment takes advantage of the fact that the bank had already introduced a mobile phone text messaging system that sends reminders to customers who have not made the required minimum payment one day after the due date. Working with the partner bank, we developed a set of additional text messages, which included basic reminders, placebo messages, messages containing a moral appeal, and messages highlighting the credit reputation consequences of delinquency. These messages were randomly assigned at the individual customer level and sent to customers who had missed the repayment due date, and had still made no payment two days before the end of a ten-day grace period granted by the bank. If no payment is received by the end of this grace period, the customer is considered delinquent, the credit card is blocked, the account is charged a

\footnotetext{
${ }^{1}$ There are also numerous references to the morality of debt in religious texts. An example from the Bible is Romans 13:7-8: "Give to everyone what you owe them [...] and let no debt remain outstanding." An example from Islam is Shahih al-Bukhari 3:575: "[...] The best among you are those who repay their debts handsomely." Many languages, including German and Hebrew, share the same word for "debt" and "guilt." Nietzsche offers a detailed account of this association and its influence on the development of moral norms in The Genealogy of Morals (1887).

${ }^{2}$ See, for example, Lee Siegel "Why I Defaulted on My Student Loans", New York Times, June 6, 2015. "Times Op-Ed Goes All In On Student Debt Silliness", Forbes, June 8, 2015.

${ }^{3}$ Not all clients of Islamic banks are motivated by religious considerations. In fact, $10 \%$ of credit card clients at our partner bank are non-Muslims. This is roughly the same as the share of non-Muslims in the Indonesian population.
} 
late payment fee, and the customer is reported to the Indonesian credit registry, which generally precludes borrowing from any formal sector lender for at least 24 months - the time period for which the negative entry remains on record - even if the debt is eventually repaid. The main outcome of interest in our experiments is therefore the discrete choice between repaying before the end of the grace period or becoming delinquent.

In the main treatment condition of our experiment, late-paying customers receive a text message which highlights that not repaying a debt when one is able to repay violates a moral norm. The message refers to the Islamic doctrine on non-repayment of debts using a quote from the Shahihal-Bukhari, one of the main religious texts of Sunni Islam, which serves as an important source for the interpretation of Islamic law and is widely known and respected among Indonesian Muslims: ${ }^{4}$

The Prophet (Peace and blessings be upon Him) says: "non-repayment of debts by someone who is able to repay is an injustice." (Imam al-Bukhari) Please repay your credit card balance at your earliest convenience. Call [customer service number].

The design of our experiment has several important features that help us identify the effect of moral appeals on debt repayment. First, debt repayment is a common and consequential financial decision, and we are able to use a real-stakes field experiment integrated into the credit card repayment cycle of a large bank to study this decision directly. Second, the text messages in our experiment are sent through the bank's automated system, allowing us to address the moral appeal to delinquent customers individually. Third, the bank routinely uses text messages to communicate with its customers, and messages with religious or moral content are not uncommon. Therefore, both the channel of communication and the content of the messages in our experiment are credible and natural in this setting. Finally, our design allows us to examine the mechanism through which moral appeals affect behavior. Many moral appeals used in practice rely on a reference to a moral authority, such as religion, family values, or the law. Our treatments isolate the moral statement from any explicit references to religion, allowing us to test whether an appeal to a moral norm without reference to a moral authority can affect behavior. Hence, while we use an Islamic credit card to obtain a setting where framing and content of the moral appeal are natural, our design allows us to identify the impact of religious context separately from that of the moral appeal itself.

We find that moral appeals increase debt repayment. In our baseline specification, receiving the moral message decreases the share of delinquent customers by 4.4 percentage points from a baseline share of 66 percent in the control group. To assess the economic magnitude of our results, we benchmark the impact of moral incentives against the effect of direct financial incentives. Our benchmark is a cash rebate treatment in which past-due customers received a message from the bank that offered them a repayment rebate in the form of principal reduction equal to $50 \%$ of their

${ }^{4}$ The Shahih-al-Bukhari is one of the six major hadith collections of Sunni Islam (Kuttub al-Sittah). It reports on the sayings, deeds, and teachings of the Prophet, and is widely used in the application of Islamic law. 
current minimum payment conditional on making a payment before the end of the grace period. While point estimates indicate moral incentives being more effective than financial incentives, we can conservatively bound the size of the cash rebates effect to be no more than 1.2 times the size of the moral message effect. This suggests that the bank would have to offer customers a principal reduction equal to at least $6 \%$ of median monthly income to generate the repayment rates observed in the moral incentives group. To rule out the interpretation that customers in our setting are simply not responsive to material incentives, we report results on the impact of reputational incentives. In this second exercise involving material incentives, past-due customers received a text message that highlighted the consequences of delinquency on the future ability to obtain credit. This message induces the strongest (9.8 percentage-point) reduction in delinquency rates. While we cannot directly assess the extent to which this treatment provides new information as opposed to bringing customers' attention to something they already knew, we know that the financial stakes of the repayment decision are meaningful - especially through the effect of a negative credit registry entry on the ability to obtain credit - and that customers respond strongly when they are reminded of these stakes.

We then use a series of additional interventions to test and rule out alternative mechanisms that could affect repayment but are unrelated to the moral appeal. First, could the impact of the moral message be due to a simple reminder effect? To test this possibility, a group of customers were sent a simple reminder message that did not contain a moral appeal. This message had no significant effect on repayment, ruling out this channel. Second, does the moral appeal work because it primes customers on religion or evokes a religious frame of mind? We examine this possibility, using a placebo message, which included a quote from the Prophet that is taken from the same religious text as the moral message but makes no reference to the Islamic doctrine on debt repayment, while still reminding the customer to repay her debt. We find that this message has no impact on repayment, which rules out an explanation of our main result based on priming religion. Third, does the moral appeal work because receiving a strongly worded message might signal that the bank is particularly committed to debt collection? To test this possibility, we surveyed customers who had received either no message, the basic reminder, or one of the versions of the moral message one day after the payment deadline. Customers were asked "How committed do you think [bank name] is to collect debt from delinquent customers?" We find no statistically significant difference in the response to this question between customers assigned to different treatments. Finally, it is worth noting that several of our text messages, including the simple reminder and the religious placebo message, were newly designed and had never before been received by the bank's customers. The fact that these messages do not affect repayment also allows us to rule out the possibility that the moral appeal is effective only because it comes in the form of a particularly novel or attention-grabbing message.

Having ruled out a number of alternative channels, we investigate the mechanism through which moral incentives affect debt repayment. The original moral incentive message explicitly quoted the 
Prophet, cited the text from which the quote was taken, and employed a word of Arabic origin for "injustice" that is often associated with religion. To examine whether the moral appeal works because of its explicitly religious connotation, we implemented two variations of the moral message, which successively removed its religious components. The first message omitted the reference to the Prophet and the religious text from which the quote was taken, allowing us to test whether invoking a credible religious source increases the effectiveness of the moral appeal. The second message additionally replaced the Arabic-origin word for "injustice" in the original message with a less formal Indonesian word, which has the same meaning but no religious connotation. This allows us to test whether the moral appeal is effective when it is unrelated to religion.

All variations of the moral appeal have very similar effets, which indicates that either customers already associate the moral appeal in the messages with religion, or that the pure moral statement is sufficient to trigger repayment. To disentangle these two explanations, we conducted a follow-up survey in which customers in the treatment and control groups were read the moral appeal and asked if they associated it with religion. The results show that this is not the case, suggesting that the effect of the moral message is driven by the moral statement it contains, rather than the religious context of the message (although part of the effect may be coming from the way religiosity interacts with the moral content of the message). We then test whether the message continues to affect repayment when it is sent repeatedly, and find that the effect of receiving the moral message a second time is very similar to that of receiving it for the first time. This indicates that the message does not work because of its novelty, or because it provides new information. Instead, our results are consistent with the interpretation that the moral message works by highlighting the fact that failing to make a payment violates a moral norm.

Finally we test whether, in addition to reducing delinquency, the moral message also affects default, defined by the bank as remaining more than 90 days past due. When customers default, the bank permanently blocks their cards and closes their accounts. Since the card is a revolving line of credit, full default is extremely costly to the borrower and a very rare event. With baseline default rates below $0.5 \%$ ( $5 \%$ in our sample of late-paying customers), it is perhaps not too surprising that our treatments do not significantly reduce default in the full sample. There is, however, substantial variation in the ex-ante credit risk of customers, and we show that the moral message significantly reduces default among customers with high predicted credit risk. ${ }^{5}$

Overall, our findings suggest that when making important financial decisions, people experience a utility cost from consciously violating a moral norm, so that moral appeals can affect behavior even when they do not mention a moral authority, threat of punishment, or adverse financial consequences.

\footnotetext{
${ }^{5}$ When we split the sample based on customers' predicted ex-ante credit risk, we find that the moral message significantly reduces default by 10.5 percentage points (from a baseline rate of 13\%) among the $10 \%$ of customers with the highest credit risk, by $4.3 \%$ (from a baseline rate of $11 \%$ ) among the $25 \%$ of customers with the highest credit risk, and by 2.2 percentage points (from a baseline rate of $8 \%$ ) for customers with above-median credit risk.
} 
This paper relates to several strands of the literature. First, our work is related to a large literature on non-monetary incentives (Frey, 1997; Akerlof and Kranton, 2000; Gneezy, 2005; Bénabou and Tirole, 2003, 2006). Moral appeals are among the most common strategies of persuasion, and many companies, for example, advertise their support for fair trade or charitable causes to influence consumer choices. ${ }^{6}$ There is a body of evidence both in the lab (see Dal Bó and Dal Bó, 2014) and in the field studying different types of normative appeals and their impact on a wide range of behaviors: from evasion of television license fees (Fellner et al., 2013), to tax compliance (Hallsworth et al., 2017, 2015), paying for newspapers (Pruckner and Sausgruber, 2013), and energy conservation (Ito et al., Forthcoming). However, to our knowledge, this paper is the first to provide field evidence that purely moral appeals can affect an important economic decision even in the absence of confounding factors, such as reminder effects, social effects, or changes in the perceived material cost of noncompliance. Moreover, we contribute to the literature by providing evidence of why these appeals work and of how effective they are relative to financial incentives. Our results also relate to a recent line of research that models what individuals pay attention to (Bordalo et al., 2013; Köszegi and Szeidl, 2013; Gabaix, 2014) and to empirical work on attention and household finance (Stango and Zinman, 2014; Zinman et al., 2017).

Second, our work contributes to a literature that examines debt accumulation and repayment (see Agarwal et al., 2009a,b; Bertrand and Morse, 2011; Zinman, 2015). In particular, Guiso, Sapienza and Zingales (2013) use survey data to study how moral considerations may play a role in strategic default in the mortgage market. They find that $82 \%$ of respondents believe that it is morally wrong to engage in strategic default, and that those who find it morally wrong are about 10 percentage points less likely to default strategically on their mortgages.

Beyond helping to understand the role of moral considerations in important economic decisions, our work also relates to a literature on religion and economic behavior (see Iannaccone, 1998; Barro and McCleary, 2006, Clingingsmith, Khwaja and Kremer, 2009, Cantoni, 2015; Campante and Yanagizawa-Drott, 2015; Bénabou et al., 2015; Benjamin et al., 2016). Identifying the effect of moral appeals linked to religion is difficult because religious activities combine moral, instrumental, and social motivations. For example, people may go to church because they believe it is the "right thing to do," but they may also do so for indirect material or social benefits, such as socializing or signaling one's beliefs or shared values. We add to this literature by showing that moral appeals can meaningfully affect behavior, even when they make no reference to a religious or moral authority, and in an environment where the social interactions usually associated with religion are absent.

The paper proceeds as follows. In Section 2, we describe the setting and experimental design. Section 3 presents the results. Section 4 interprets our findings, and Section 5 concludes.

\footnotetext{
${ }^{6}$ Most closely related to our setting, a number of banks have used television commercials with moral content to get delinquent borrowers to repay their debt. For example, Indian banks have aired television and radio commercials with moral appeals made by children in an effort to persuade defaulting borrowers to repay their loans. See "Banks Make Emotional Appeals to Get Borrowers to Repay Loans " Live Mint, October 2016.
} 


\section{Experimental Design}

\subsection{The Credit Card}

We design a natural field experiment with the universe of late-paying customers of Indonesia's most popular Islamic credit card. The credit card is issued by one of the country's leading Islamic banks, which offers credit cards as part of its portfolio of Islamic consumer finance products. Originally introduced in 2009, the card had approximately 200,000 customers at the time of our experiment.

The credit card features are designed to comply with the principles of Islamic law which, among other prescriptions, prohibits charging interest and investing in activities considered contrary to the principles of Islam. In order to be fully consistent with Islamic law, the features of the card are based on a fatwa (legal decree) issued in 2006 by the Indonesian Council of Islamic Scholars that lays out the guidelines under which banks can offer Sharia-compliant credit cards. Following these guidelines, the credit card is structured as an Ijara fee structure contract, which means that customers pay a fee for the transaction services provided by the card instead of a variable interest rate. Customers are charged fixed annual fees of Rp 120,000 (US\$10) for a basic card, Rp 240,000 (US\$ 20) for a gold card, and Rp 600,000 (US\$ 45) for a platinum card, plus a monthly membership fee of $2.75 \%$ of the customer's credit limit. This monthly fee can be partially or fully waived through a "cash rebate," which is proportional to the customer's available credit and can range from zero to the total amount of the monthly fee. ${ }^{7}$ The fee is waived entirely if there is no outstanding debt.

There is a monthly billing cycle, with a billing date on the eighteenth day of each month. The minimum monthly payment, equal to either $10 \%$ of the customer's total outstanding balance or Rp 50,000 (whichever amount is higher) plus eventual arrears and overdrafts, is due on the eighth day of the following month. Customers who do not meet the minimum payment by the due date receive a text message from the bank on the following day. The bank grants customers who miss the due date a grace period of ten days, which ends on the eighteenth day of each month (we refer to this date as the "repayment deadline"). Customers who do not make the minimum payment by this date are considered delinquent and reported to the Indonesian credit registry, the Sistem Informasi Debitur, which all banks consult before issuing credit. Even if the debt is eventually repaid, this negative entry remains on record for 24 months and precludes borrowing from any formal sector lender for that period of time. Additionally, delinquent customers are charged a nominal late payment fee, ranging from $\mathrm{Rp} 15,000$ to $\mathrm{Rp} 35,000$ and their card is automatically blocked. ${ }^{8}$ Once the customer makes the minimum payment, the card is immediately unblocked.

\footnotetext{
${ }^{7}$ The cash rebate is calculated as follows: cash rebate $=2.75 \% \times$ (credit limit - amount outstanding). The net monthly fee is the monthly membership fee minus the cash rebate, that is, $2.75 \% \times$ amount outstanding.

${ }^{8}$ Late payment fees increase over time. For example, customers who are more than 30 days late are charged additional fees ranging from $\mathrm{Rp} 20,000$ to $\mathrm{Rp} 50,000$. To be compliant with Islamic law, the bank is allowed to charge late fees only to compensate for the costs of debt collection, including follow-up and legal costs. In our sample, the average customer who is in default until the point where the bank hands over the account to an outside collections agency has been charged late fees of between Rp 530,000 (US\$40) and Rp 1,320,000 (US\$100).
} 
If a customer's minimum payment remains outstanding for more than 90 days after the due date, the customer is considered in default, the card is permanently blocked and the account is closed. Accounts that remain more than 120 days overdue are sent to the bank's collections department and, eventually, an outside collection agency. Figure 1 summarizes the credit card billing cycle and the timeline of our intervention.

\subsection{Sample Population and Random Assignment}

The population for our experiment comprises the 14,429 credit card customers who were more than one week past due on their minimum payment at least once during one of the six months between February 2015 and April 2016 in which the experiment was carried out. ${ }^{9}$ Because some customers were late more than once during this period, there are 23,520 observations in our sample frame. ${ }^{10}$

The experiment was conducted in six waves, coinciding with the monthly credit card repayment cycle. ${ }^{11}$ Each month, the bank shared with us the list of customers that had not made the minimum required payment by the sixteenth day of the month (two days before the final repayment deadline at the end of the ten days grace period) but were otherwise current on their payments schedules (that is, made the previous month's payment). In the main experiment, we excluded from this list all customers who had previously received a text message treatment. Customers assigned to the control group in a previous month remained in the sample and could either be assigned to one of the treatments or form part of the control group again. ${ }^{12}$ For example, in March 2015, 4,803 customers were more than a week late. Out of these, 1,018 had previously received a treatment message and were thus excluded from the sample; the remaining 3,785 customers were assigned to one of the treatment conditions or the control group. Following this process, we obtain a dataset

\footnotetext{
${ }^{9}$ The experiment was conducted in February, March, May, and June 2015, and February and April 2016. We originally planned to have a treatment group receiving restructuring offers in April 2015, but the partner bank was not able to operationalize this. Upon agreement with the bank, we then decided to pause our main intervention in April 2015 and to resume it in May 2015. We also ran a small pilot with 250 customers in January 2015 that had results similar to those in our main intervention.

${ }^{10}$ In the universe of 14,429 customers, 8,691 were late only once, while the remainder appeared in our sample more than once: 3,052 customers were late twice, 1,414 were late three times, 579 four times, 191 five times, and 52 were late in all six months.

${ }^{11}$ The first three waves of the experiment were conducted in February, March, and May 2015. The last three waves were conducted in June 2015, and February and April 2016. As part of a parallel experiment for a second paper, we had two other treatment groups with customers receiving multiple text messages on the same day. We excluded those 2,200 observations from our analysis. Results are unaffected when these observations are included, and are displayed in Table A.4 in the Supplementary Appendix. In the notes to Table A.4 we also discuss some design and implementation issues which affect that interpretation of the effect of these additional treatments.

${ }^{12}$ When looking at a long term outcome like default, we exclude those customers who were in the control group in a month, reappeared in the sample in a following month, and were randomized to receive a treatment message before their long term behavior was measured. Indeed, for these customers long term outcomes in the control condition are not observable. The outcomes are however observed for similar customers who were re-randomized in the control condition again. To maintain representativeness, when looking at default we re-weight the sample by giving more weight to these latter customers who appeared in the control group more than once.
} 
that includes 13,428 observations, representing 12,104 unique credit card customers. ${ }^{13}$

Eligible customers were randomly assigned to one of several treatment conditions or to a control group. As part of the bank's standard communications policy, all customers received a neutral text message reminder one day after they had missed the due date (that is, when they were one day past due). The 4,120 customers assigned to the control group received no other text from the bank, while the 9,308 customers assigned to one of the treatment conditions received additional information through a text message sent two days before the repayment deadline (that is, when they were seven days past due). All treatments were randomly assigned at the individual customer level and delivered through text messages using the bank's existing customer notification system. ${ }^{14}$ Appendix Figure A.2 summarizes the experimental design.

In February and April 2016, we conducted a separate follow-up experiment with the 898 customers who reappeared on the list of late payers and had previously received the moral message as part of the main experiment. The experiment was designed to test if the moral message only works the first time it is sent - for example, because it is novel or conveys new information - or if sending the message repeatedly can still affect repayment. Following the same procedure and timing as above, recurrent late payers were randomly assigned either to a control group or to a repeated message treatment group. ${ }^{15}$ The 450 customers assigned to the control group again only received a neutral reminder one day after they missed the due date. The 448 customers assigned to the repeated moral message treatment group received a moral message identical to the one they had previously received. As in the main experiment, this message was sent two days before the repayment deadline at the end of the ten-day grace period.

\subsection{Experimental Treatments}

\subsubsection{Control Group}

A total of 4,120 customers were assigned to the control group, which forms the basis of comparison throughout the experiment. Customers in this group received a single reminder one day after they had missed the required minimum monthly payment:

\footnotetext{
${ }^{13}$ Of these 13,428 observations, 10,903 customers appear on the list of late-payers only once, 1,088 appear twice (the first time in the control group), 104 appear three times (the first two in the control group), 6 appear four times (the first three in the control group), and 1 customer appears 5 times (the first four times in the control group). Although this approach does not affect the internal validity of our analysis, it could potentially reduce the representativeness of our sample, since in a given month, customers who received a previous treatment message could have been part of the list of late payers if they had been assigned to the control group instead. However, given that the effect of our treatments is very similar for subjects appearing in the sample for the first time and those previously assigned to the control group, re-weighting the sample to correct for the probability of being excluded does not affect our results.

${ }^{14}$ All messages were in Bahasa Indonesia, the official language of Indonesia, which is also the standard language used by the bank in all of its customer communications.

${ }^{15}$ We stratify on how recently the customer had received the first moral message: 364 customers were treated two months before reappearing in the late-payer list, while the other 534 customers were treated for the first time between eight and fourteen months before.
} 
Your [name of the card] has reached the due date. Please make a payment at your earliest convenience. If you have already paid, ignore this text. Call [customer service number].

While all other customers received an additional message from the bank two days before the repayment deadline, customers in the control group received only this initial reminder.

\subsubsection{Moral Incentives}

To test the impact of moral appeals, we assigned 2,244 participants to the moral incentive treatment condition. In addition to the basic reminder sent to all customers who missed the due date, these customers received an additional message drawing attention to the religious implications of not repaying their debts. The message quotes from the Shahih al-Bukhari, one of the main religious texts of Sunni Islam, which reports of the teachings, deeds, and sayings of the Prophet Muhammad and serves as one of the main sources for the interpretation of Islamic law. The quote highlights the religious doctrine on repayment of debts and asks the customer to repay her outstanding balance:

The Prophet (Peace and blessings be upon Him) says: "non-repayment of debts by someone who is able to repay is an injustice" (Imam al-Bukhari). Please repay your credit card balance at your earliest convenience. Call [customer service number].

To better understand the mechanisms underlying the impact of moral appeals, the bank sent two additional variations of this treatment, which varied the degree of its religious content. The first variation of the message (the implicit moral incentive condition) removed the reference to the Prophet and the text from which the quote was taken, but kept the Arabic-origin word for "injustice" from the original quote, which may be associated with religion. This message, assigned to 1,186 customers, reads:

Non-repayment of debts by someone who is able to repay is an injustice. Please repay your credit card balance at your earliest convenience. Call [customer service number].

The second variation of the message (the non-religious moral incentive condition), which was assigned to 1,180 customers, not only omitted the reference to the Prophet and the source of the quote, but also replaced the Arabic-origin term for "injustice" (kezaliman) with the standard Indonesian word (ketidakadilan), which has no religious connotation.

The first variation of the moral message allows us to test whether a moral appeal is strength-

ened by invoking a credible religious source. The second message tests whether receiving a moral statement without religious connotation can affect the repayment decision. 


\subsubsection{Direct Financial Incentives: Cash Rebate}

To benchmark the effect of moral appeals against direct financial incentives, we implemented a treatment consisting of a direct one-time monetary incentive in the form of a large cash rebate. In this treatment, the bank sent the standard reminder on the due date and an additional message two days before the repayment deadline, in which customers were offered a rebate equal to $50 \%$ of their currently outstanding minimum payment, conditional on making the required minimum payment by the deadline. ${ }^{16}$ The rebate would then be credited against expenditures in the next billing cycle starting three days after the offer is made, so that the reward is available to customers practically right after they make a payment. The financial incentive message was assigned to 336 participants and reads as follows:

This month, make your credit card payment to get a cash rebate equal to $50 \%$ of your minimum payment on your next statement. Please repay your card balance at your earliest convenience. Call [customer service number].

For this treatment to serve as a useful benchmark, customers need to understand the message and know that the size of the rebate is independent of their future behavior. Since the rebate is a conditional offer, one might be concerned that customers might misinterpret the offer. We took several steps to verify that this was not the case. First, the rebate offer was designed in close cooperation with the bank, and we ensured that the wording was clear and similar to the bank's usual customer communications. ${ }^{17}$ Second, we closely monitored the treatment implementation and found no indication that customers were confused about the offer, or contacted the bank with requests for clarification. Since the rebate is credited in the next billing cycle (which starts three days after a customer receives the financial incentive offer), one could also be concerned that customers might erroneously believe that the incentive is proportional to the payment due in the following cycle, as opposed to the current amount due, which comprises expenditures for the previous billing cycle, which ended before the rebate was offered. If customers erroneously consider the size of the rebate to be under their control, one would expect them to reduce current repayment and increase spending to increase the rebate amount. We test for this and find that neither of these patterns are present in the data. There were also no instances in which a customer disputed the rebate amount they received. Finally, we conduct a customer survey, to measure respondents' preferences for deposits on their checking account versus statement credit which verified that customers value a cash rebate in the form of statement credit nearly as much as immediate cash. ${ }^{18}$ We can thus

\footnotetext{
${ }^{16}$ The current minimum payment is based on spending in the previous billing cycle and therefore unaffected by the borrower's current or future spending.

${ }^{17}$ The bank frequently uses rebates and discount offers in its marketing activities, so that customers in our sample were familiar with this type of offer. Moreover, as described above, a cash rebate similar to our treatment, is an inherent feature of the card's pricing structure.

${ }^{18}$ See sections 2.4 .2 and 3.2 for more details on the survey.
} 
reliably use this treatment to measure the effect of moral incentives, and express it in terms of the size of conditional principal reductions the bank would have offer to achieve a similar reduction in credit card delinquencies.

\subsubsection{Indirect Financial Incentives: Credit Reputation}

To test the effect of indirect financial incentives, we implemented another treatment, consisting of a message that highlighted the negative effect of non-repayment on the customer's credit reputation and ability to obtain credit in the future. In this credit reputation incentive condition, customers received the standard reminder on the due date and an additional message two days before the repayment deadline. The message stated that non-repayment will result in the customer being reported to the Indonesian credit registry, the Sistem Informasi Debitur, which will diminish the customer's access to credit in the future. This message was assigned to 2,000 customers and reads as follows: ${ }^{19}$

Late payments are reported monthly to Bank Indonesia Sistem Informasi Debitur (SID), which all banks consult. This will diminish your ability to get credit in the future. Please repay your card balance at your earliest convenience. Call [customer service number].

\subsubsection{Placebo: Simple Reminder}

We assigned 1,362 customers to the simple reminder placebo treatment condition. Customers in this treatment received the standard reminder on the due date and an additional neutral reminder two days before the repayment deadline. ${ }^{20}$ This second reminder is similar to the message sent to all customers who miss the due date and makes no reference to the moral or financial implications of non-repayment:

The due date of your [name of the card] bill was on [due date] and your payment has not been received yet. Please repay your credit card balance at your earliest convenience. Call [customer service number].

This treatment tests how receiving a second reminder affects repayment through channels such as limited attention and memory. Comparing its effect to that of moral incentives allows us to distinguish the impact of moral appeals from the effect of receiving additional reminders.

\footnotetext{
${ }^{19}$ We designed two variations of this text message and randomly assigned 1,000 customers to each of two subgroups. The first subgroup received the message in the main text. The second group received a text that says "Late payments are reported monthly to Bank Indonesia Sistem Informasi Debitur (SID), which all banks can consult. Please repay your card balance at your earliest convenience. Call [customer service number]." We pool these two treatments in our analysis, since their effect on repayment is not statistically different.

${ }^{20} \mathrm{~A}$ number of customers were included in this treatment in the last wave of the experiment to compare the effect of the moral incentive to that of a simple reminder on outcomes measured in a phone survey. The survey asked whether customers would like to receive the same text message again, and how committed they thought the bank is at collecting debt. The survey instrument is available in the Supplementary Appendix.
} 


\subsubsection{Placebo: Religious Message}

Finally, we assigned 1,000 customers to a religious placebo treatment. This treatment is designed to address the possibility that borrower behavior could be affected purely by being primed on religion. ${ }^{21}$ Customers in this group received the standard message on the due date and an additional message with a quote from the Prophet taken from the same source used in the moral incentive treatment two days before the repayment deadline. However, in contrast to the moral incentive message, this quote made no reference to financial matters or debt repayment:

The Prophet (Peace and blessings be upon Him) says: "When Allah wishes good for someone, He bestows upon him the understanding of the Book" (Imam al-Bukhari). Please repay your credit card balance at your earliest convenience. Call [customer service number].

This treatment allows us to test whether moral appeals work because they highlight the moral implications of a specific action, the non-repayment of debts, or simply because they remind recipients of the religious nature of their contract with the bank or evoke a religious frame of mind.

\subsection{Data and Summary Statistics}

The dataset we use in our analysis combines the results from the experiment, administrative data from our partner bank, and information from a number of follow-up surveys phone surveys administered to the bank's customers.

\subsubsection{Administrative Data}

We first obtained bank data on customer account characteristics (age, gender, religion, province of residence, monthly income, and credit limit) for the universe of past-due customers participating in the experiment. Table 1 reports summary statistics and presents a test of random assignment. ${ }^{22}$ The median credit card customer in our sample is male, 41 years old, has a monthly income of Rp 5,000,000 (US\$ 375), a credit limit of Rp 10,000,000 (US\$ 750) and an outstanding debt of Rp $7,739,015$ (US\$ 580) on the credit card. ${ }^{23}$ As expected from random assignment, the sample is well balanced across all baseline characteristics. ${ }^{24}$

\footnotetext{
${ }^{21}$ Laboratory experiments have shown that religious primes can induce prosocial behavior, increasing the amount shared in dictator games (Shariff and Norenzayan, 2007), reducing cheating (Randolph-Seng and Nielsen, 2007; Mazar et al., 2008), and increasing charitable donations (Pichon et al., 2007). Priming religion also increases punishment of unfair behavior, but only among religiously committed subjects (McKay et al., 2011; Laurin et al., 2012).

${ }^{22}$ See Table A.2 in the Supplementary Appendix for summary statistics and a test of random assignment for the follow-up experiment.

${ }^{23}$ For comparison, Indonesian per capita income was US $\$ 3,491$ (approximately US $\$ 291$ per month) at the time of the experiment (World Bank, 2014).

${ }^{24}$ Our sample is also very similar to the universe of the bank's credit card customers along most observable dimensions. Late payers are only marginally more likely to be female ( $40 \%$ female versus $37 \%$ male) and, on average,
} 
In a second step, the bank shared data on credit card repayment for customers in our sample after each wave of the experiment as well as historical repayment data covering the 12 months before our intervention. In the monthly repayment data, we observe a customer's delinquency status (whether the customer made the required minimum monthly payment by the end of the grace period), which is the main outcome of interest for our analysis. In August 2015, the bank also provided further financial data, including information about savings accounts and repayment behavior, for the customers already in our sample by that time. In particular, we collected data on savings account balances for all customers in the first four waves of the main experiment who also have an account with our partner bank. ${ }^{25}$ The bank also provided us with data on default as of August 2015. Default is defined by the bank as failing to make the minimum payment within 90 days of the repayment deadline. ${ }^{26}$ The card of a customer in default is permanently blocked, and her account is closed.

\subsubsection{Survey Data}

We combine data from the experiment with information from a number of phone surveys administered to the population of credit card customers. ${ }^{27}$ The main survey, conducted in June and July 2015, asked respondents about their level of religiosity and their familiarity with the quote used in the three variations of the moral incentive treatment condition. The same survey was also administered to a randomly drawn sample of the bank's credit card customers all over Indonesia who were not late in their payments during the study period. We use the results from this survey to construct a measure of local religiosity for the regions in which credit card customers reside.

An additional survey was administered one day after the repayment deadline in April 2016 to a random sample of credit card customers who had participated in the experiment on that month. The purpose of this survey was to test whether the moral appeal signals that the bank is particularly committed to collected its debt, whether receiving it causes any disutility to customers, and to measure whether the reputational message increases knowledge about the credit reporting system. Respondents in this survey had received either no message, the basic reminder, or one of the versions of the moral message. The survey first asked these customers how committed they thought the bank was to collect debts. Second, it asked whether they wished to receive text messages like the one they had received a few days earlier in the future. Third, customers were randomized in two groups: those in a treatment group were read the content of the reputational incentive message, while those in a control group were not given any information. All customers were then

have a slightly lower credit limit (Rp 13.5 million versus $\mathrm{Rp} 14.7$ million).

${ }^{25}$ The bank's customers are not required to have a checking or savings account to open a credit card. The most common deposit account within the bank is a liquid savings (tabungan) account. In our 2015 sample, 30 customers had a checking account and 1,088 customers have a savings account at the bank.

${ }^{26}$ At the time this data was collected, the default outcome was thus realized only for customers in the first three waves of the main experiment, the third wave being May 2015.

${ }^{27}$ The survey instruments are available in the Supplementary Appendix. 
asked questions about the Indonesian credit registry and their beliefs about the consequences of non-repayment.

In April 2017 we selected a random sample of credit card customers for a final survey. These were customers who had participated in the experiment in June 2015 - the month in which the cash rebate treatment was conducted - but were not offered the rebate. The purpose of the survey was to elicit customer preferences for an immediate deposit in their bank account relative to a delayed cash rebate on their next credit card statement (identical to how the cash rebate treatment was executed) using a non-incentivized multiple price list procedure. ${ }^{28}$

\subsubsection{Main Outcome of Interest}

Our main outcome of interest is delinquency. Recall that the bank considers a customer to be delinquent if the customer fails to make a payment by the end of the ten-day grace period, which happens at the eighteenth day of the month. Accordingly, we measure delinquency as a dummy variable indicating whether a customer fails to make the minimum required payment by the end of the grace period. Delinquent customers and immediately reported to the credit registry, their cards are automatically blocked, their accounts are charged late payment fees, and they may receive phone calls from the bank's collection department.

\subsection{Estimation}

Since treatment status was randomly assigned, our identification strategy is straightforward. We identify experimental treatment effects using regressions of the form:

$$
Y_{i}=\alpha+\sum_{c} \beta_{c} I_{c, i}+\gamma^{\prime} \mathbf{X}_{i}+\epsilon_{i}
$$

where $Y_{i}$ is an outcome variable, such as an indicator for customer $i$ being delinquent on her debt. The variables $I_{c, i}$ are indicators for customer $i$ being in condition $c$, where $c$ denotes the experimental treatment condition to which customer $i$ was assigned. In some specifications, we additionally include a vector of control variables, $\mathbf{X}_{i}$, which contains either month fixed effects only, or month fixed effects as well as a set of customer and account characteristics. In all regressions, the omitted category is the control group, which received only a basic reminder on the due date

\footnotetext{
${ }^{28}$ The survey conducted in June and July 2015 was administered to 2,273 participants of our experiment and to other 567 randomly selected customers. The survey conducted in April 2016 was administered to 151 randomly selected participants of the experiment that month, stratified by treatment group. Finally, the survey conducted in April 2017 was administered to 98 customers who are similar along observables to the 336 customers who received the cash rebate. Response rates and initial sample sizes for these surveys are respectively $43 \%$ and $5,233,38 \%$ and $1,499,22 \%$ and 700 , and $25 \%$ and 400 . In some of these surveys, response is correlated with observables (for example, in the first survey women are less responsive than men), but it is never correlated with treatment assignment.
} 
but no second text message two days prior to the deadline. ${ }^{29}$

The results reported in the Tables are based on sampling-based inference. In the text, we also report the results of randomization-based inference, where we calculate Fisher exact p-values for the sharp null hypothesis of no effect. As sample statistics, we use the difference in means by treatment status. Given the large sample size, calculation of the sample statistic for all possible realizations of the treatment assignment mechanism is computationally not feasible. For this reason, p-values for our permutation tests are based on 10,000 iterations using random sampling with replacement from the universe of possible treatment assignments, while holding the probability of being treated constant. To compare the effect of different treatments to the one of moral incentives, in the text we also present $95 \%$ confidence interval of the ratio between the effect of those treatment and of moral incentives.

\section{Results}

\subsection{Main Results: Moral Incentives}

We first examine the effect of the moral message on delinquency. Table 2, shows treatment effect estimates for the moral incentive message across all waves of the experiment. In column (1), we begin by presenting results from a regression without controls, which represent raw delinquency rates. Compared to the control group, the share of delinquent customers decreases by 4.4 percentage points (from $66 \%$ in the control group) under the moral incentive treatment condition. The difference in delinquency rates is significant at the 1 percent level ( $\mathrm{p}$-value $<0.001$ ). Using randomization-based inference, we also reject the null hypothesis that the moral incentive treatment had no effect (Fisher exact p-value $=0.001)$. We add month fixed effects in column $(2)$ and customer-level covariates in column (3). The results remain very similar across all specifications, with treatment effects ranging from -4.4 percentage points to -5.2 percentage points from the $66 \%$ delinquency rate in the control group, indicating that the randomization was successful. The treatment effect is similar for men and women, and also does not differ by age, religion, or whether a customer has appeared on the list of late payers at least once in the year before our intervention. ${ }^{30}$ The effect is stronger for customers with a lower debt-to-income ratio, suggesting that the treat-

\footnotetext{
${ }^{29}$ Since we do not observe whether customers open the messages they receive, all of our results should be interpreted as ITT estimates. Note, however, that all messages are sent from the bank, so that there is no reason to believe that customers are more or less likely to open messages associated with a specific treatment.

${ }^{30}$ Fewer than $10 \%$ of customers in our sample are non-Muslim, so that it is not possible to estimate this effect precisely. We discuss heterogeneity by local religiosity in Section 4.1.1. Heterogeneous treatment effects are reported in Table A.3 in the Supplementary Appendix. Importantly, the fact that the effect is the same for customers who have been delinquent in the previous six months and customers who have not, implies that customers who generally pay late and customers who generally pay in time are equally responsive to moral appeals and suggests that our estimates could potentially generalize to the population of customers who typically repay their card debt in time in the absence of any intervention.
} 
ment response is moderated by financial constraints. We find that the same pattern also holds for the credit reputation treatment.

\subsection{Benchmarking the Moral Incentive Effect}

\subsubsection{Direct Financial Incentives: Cash Rebate}

To assess the economic magnitude of the moral incentive effect, we conduct a benchmarking exercise in which we compare the impact of the moral message against that of financial incentives. This benchmarking exercise allows us to measure the impact of moral incentives in monetary terms and identify the amount of financial incentives the bank would need to provide to generate the same reduction in delinquency rates as the moral incentive message. To do so, we use a benchmarking treatment, in which the bank sent text messages to a randomly chosen subset of customers and offered them a cash rebate in the form of a principal reduction equal to $50 \%$ of their outstanding minimum payment, conditional on making the required payment before the deadline. The customers in this group were informed that this rebate would be credited to their account in the next billing cycle. The median rebate offered was Rp 380,000 (equal to $8 \%$ of monthly earnings for the median customer in our sample), and the average rebate offered was $\mathrm{Rp} 500,000$.

The results of the financial incentive benchmarking treatment are reported in Table 3 . We do not find a statistically significant effect of financial incentives on repayment, nor a significant difference between the effect of moral and financial incentives. ${ }^{31}$ This is mainly due to the limited sample size, which was the result of the partner bank not wanting to incur the comparatively high cost of the rebate ( $\mathrm{Rp} 580,000$ for the average person who took up the offer, compared to practically no cost for the moral message).

We can nonetheless use the results to obtain a conservative benchmark for the size of the moral incentive effect. While point estimates indicate moral incentives being more effective than financial incentives, we can use the confidence interval to conservatively bound the effect of moral incentives to be at least $84 \%$ of the effect of financial incentives. This suggests that moral incentives are at least as effective as a statement credit reward of $\operatorname{Rp} 317,726$ (1/1.196, or $84 \%$ of the median rebate offered) or approximately $6 \%$ of median monthly income. ${ }^{32}$

\footnotetext{
${ }^{31}$ In the month when both treatments were run concurrently, point estimates indicate that the cash rebate treatment had an effect of -2.1 percentage points compared to -5.4 points for moral incentives. The $95 \%$ confidence interval for the ratio between the coefficient of financial incentives and of moral incentives is [-1.069; 1.196$]$.

${ }^{32}$ Because the cash rebate treatment is a conditional offer, credited to a customer's account in the next month, we conduct several exercises to rule out potential confounding factors. First, we ensure that borrowers are not confused about the content of the offer and timing of the rebate. We closely monitored the implementation and found no instances in which customers asked questions indicating that they had not understood the offer or contacted the bank with fuerther questions or complaints about the offer. Second, we conduct an elicitation exercise (using a nonincentivized phone survey with past-due clients) to show that customers do not strongly discount statement credit relative to immediate cash deposits. This exercise indicates that on average customers value $\mathrm{Rp} 100$ in statement credit next month the same as an immediate Rp 93 cash deposit into their account. Importantly, $80 \%$ of customers value a statement credit exactly the same as immediate cash, and even the lowest decile values statement credit as
} 


\subsubsection{Indirect Financial Incentives: Credit Reputation}

The results in Section 3.2 suggest that customers react more strongly to moral incentives than to significant financial incentives. In principle, this pattern could be due to the particular setting in which our experiment is conducted: one may worry that customers of an Islamic bank are perhaps especially unresponsive to material incentives. To address this possibility, we estimate the impact of reputational incentives - another type of material incentive that has been shown to be important in other contexts (see Liberman, 2016). Our test uses a treatment in which the bank sent text messages that informed late-paying customers of the existence of the Indonesian credit registry, and the consequences of being reported for non-repayment. The message stated that all banks in Indonesia consult the credit registry before issuing credit, so that a registry entry will prevent a customer from accessing formal credit in the future. ${ }^{33}$

Table 4 reports results. In terms of raw delinquency rates, reported in column (1), the credit reputation message decreases the probability of becoming delinquent by 9.8 percentage points, as compared to 6.0 percentage points for the moral incentive message over the same time period. We can use randomization-based inference and reject the sharp null hypotheses that reputational incentives had no effect (Fisher exact p-value $<0.001$ ), or that they had the same effect as the moral incentive message (Fisher exact $\mathrm{p}$-value $=0.046)$. The results remain very similar in columns $(2)$ and (3), where we add month fixed effects and covariates. ${ }^{34}$ These results indicate that customers in our sample do respond to the material incentives linked to their credit reputation. As above, we can calculate the $95 \%$ confidence interval for the ratio between the cash rebate coefficient and the credit reputation coefficient, and use it to obtain a conservative benchmark for the size of the reputational incentive treatment effect. In this case, the confidence interval is [-0.524;0.586], implying the effect of reputational incentives to be at least $171 \%$ of the effect of financial incentives. This suggests that the bank would have to offer a statement credit reward of Rp 648,464, or approximately $13 \%$ of median monthly income, to obtain the same effect as the credit reputation message. If we assume that the credit reputation treatment moves beliefs about the probability of the existence of the credit registry from zero to one, we can interpret this number as the willingness to pay for a clean credit record. ${ }^{35}$ Liberman (2016) shows that credit card borrowers in Chile are willing

much as an immediate Rp 90 cash deposit. At the same time, $6 \%$ of customers do not give any value to a principal reduction. This is consistent with these customers planning to default on their debt and completely discounting a statement credit: default rates in our sample are indeed about $5 \%$ in our sample of late-payers (below $0.5 \%$ in the entire customer population).

${ }^{33}$ Survey evidence indicates that this treatment does not necessarily increase customers' knowledge of how the registry functions but instead simply makes customers think that the consequences of being reported to the credit registry are severe.

${ }^{34}$ The $95 \%$ confidence interval for the ratio between the credit reputation and moral incentive coefficients is [1.041; 3.059].

${ }^{35}$ The assumption that probabilities shift from zero to one gives the most conservative estimate of the willingness to pay for a clean credit record: any other intermediate shift in beliefs would results in a higher estimate of the willingness to pay. 
to pay $11 \%$ of their median monthly income to maintain a clean credit record, so that our results provide suggestive evidence that the customers in our setting are not less responsive to reputational incentives than customers of a regular bank in another emerging economy. ${ }^{36,37}$

\subsection{Ruling Out Other Mechanisms}

The results so far establish that receiving a moral message substantially decreases credit card delinquency. However, there are several mechanisms other than responsiveness to the moral appeal that could explain this effect. In this section, we present a number of tests to evaluate alternative channels and show which of these potential explanations can be ruled out.

\subsubsection{Reminding Customers}

First, receiving a text message might increase repayment rates simply because it acts as a reminder, irrespective of whether the message contains a moral appeal or not (see, for example, Karlan et al., 2016b). To address this possibility, we compare repayment in the moral incentive treatment group to repayment among customers assigned to the simple reminder placebo treatment, which consisted of a basic non-religious reminder that made no reference to morality or religion and was sent at the same time as the moral message. The results, reported in Table 5, show that receiving the simple reminder has no effect on repayment. The raw delinquency rate is $65 \%$ in the group receiving the basic reminder, compared to $66 \%$ in the control group. The p-value of the difference between the simple reminder and the control is 0.714 (Fisher exact p-value $=0.725$ ), and the pvalue of the difference between the simple reminder and the moral message is 0.013 (Fisher exact $\mathrm{p}$-value $=0.015)$. We can therefore rule out that the moral message works simply because it reminds customers to repay their debt. ${ }^{38}$

\footnotetext{
${ }^{36}$ Note that it is difficult to use the credit reputation treatment as a direct benchmark as it combines the effect of learning about the existence if the credit registry and being made aware of the consequences of non-repayment. To gain a better understanding of how the credit reputation treatment affects customers' decisions, a small survey was conducted in April 2016. Customers were randomized in two groups: customers in a treatment group were read the content of the reputational incentive message, and customers in a control group were not given any information. All participants were then asked some questions about the Indonesian credit registry. The results from the survey suggest that late paying customers are poorly informed about the functioning of the credit registry, and that the reputational incentive message does not increase their knowledge of how the registry functions. Instead, the message seems to make customers believe that the consequences of being reported to the credit registry are more severe.

${ }^{37}$ In an additional benchmarking exercise, we express the impact of the moral incentives in terms of persuasion rates, as suggested by DellaVigna and Gentzkow (2010), which makes it possible to compare the impact of moral incentives to effect sizes from other studies that have used non-monetary incentives. The persuasion rate of an intervention is defined as the change in behavior generated, scaled by exposure to the treatment and the population share left to be persuaded. Formally, this can be expressed as $f=100 * \frac{y_{T}-y_{C}}{e_{T}-e_{C}} \frac{1}{1-y_{0}}$, where where $e_{i}$ is the share of group $i$ receiving the message, $y_{i}$ is the share of group $i$ adopting the behavior of interest, and $y_{0}$ is the counterfactual share that would change behavior if there were no message. Using this approach, we show that the magnitude of the moral incentive effect (persuasion rate of approximately 7\%) is comparable to the impact of other types of non-monetary incentives documented in the literature. See Appendix Table A.9 for details.

${ }^{38}$ See Appendix Table A.10 for results where the simple reminder is used as the main comparison group.
} 


\subsubsection{Priming Religion}

Second, receiving a text message with religious content could affect the repayment decision through priming effects, which are also unrelated to moral suasion. The moral message might, for example, remind recipients of the religious connotation of the credit contract or evoke a religious frame of mind more generally. To rule out this possibility, we compare repayment in the moral incentive treatment group to repayment among customers who received the religious placebo message. The religious placebo message contains a quote from the Prophet that is taken from the same religious text as the quote used in the moral message but makes no reference to the Islamic doctrine on debt repayment while still reminding customers to repay her credit card debt. The results, reported in Table 5, show that the religious placebo message has no effect on the repayment rate. The raw delinquency rate is $65 \%$ in the group receiving the religious reminder and nearly identical to the delinquency rate in the control group. The p-value of the difference between the religious placebo and the control is 0.889 (Fisher exact p-value $=0.907$ ), and the p-value of the difference between the religious placebo and the moral message is 0.007 (same as the Fisher exact p-value), indicating that the effect of the moral message is also not driven by priming religion.

\subsubsection{Novelty of the Message}

Third, customers may respond to the message not because of its moral content, but because it is novel or attention-grabbing. To test for this possibility, we consider delinquency rates under different text message treatments that use new content. Note that several of the messages that were sent to credit card customers as part of the experiment-including the simple reminder, religious placebo, and financial reminder messages- were specifically designed for the study, and had never been received by any of the bank's customers before. The fact that none of these messages had a statistically significant effect on repayment allows us to rule out that the effect of the moral message is explained by the novelty of the message. We can also rule out the possibility that receiving a message with a quote from the Prophet is particularly attention-grabbing. The religious placebo message also uses a quote from the Prophet, which is very similar to that in the moral incentive treatment and taken from the same religious text. However, as we show above, this message has no effect on repayment.

\subsubsection{Signaling the Bank's Commitment to Debt Collection}

Finally, since customers had previously received a text message at the time of the due date, receiving a second message could be perceived as a signal that the bank is particularly committed to debt collection, which could affect delinquentcy rates independent of the moral appeal. To address this possibility, we conduct the following test.In April 2016, the bank the sent placebo messages and the three variations of the moral message discussed above to customers never treated before. 
Another group of customers was randomly assigned to a control group and received no message. We conducted a phone survey with customers in both groups the day after the payment deadline and asked "How committed do you think [bank name] is to collect debt from delinquent customers on a scale from 1 to 5 (where 1 is not very committed, and 5 is very committed)?" The percentage of respondents that answered 4 or 5 is $76 \%$ in the control group, $67 \%$ in the basic reminder group, and only $59 \%$ among customers that received a moral message (the p-value for the test of equality of all three coefficients is 0.302 , and the p-value of the test of equality between respondents in the control group and the treatment group is 0.124 ). Hence, there is no evidence to suggest that receiving the moral message is perceived as a signal that the bank is now more committed to enforce debts. ${ }^{39,40}$

\subsection{Disutility from Receiving the Message}

While the results described previously show that moral incentives are effective at getting customers to repay their credit card debt, it is unclear if this comes at a utility cost to customers. To understand this issue, in the last month of the intervention the bank called back customers who had received either the simple reminder or one of the versions of the moral incentive message as part of a follow-up survey one business day after the messages were sent (messages were sent on Friday and surveys were conducted on the next Monday). These customers were asked the question "[Bank name] is sending reminder messages to its customers to help them make their payment on time. You received one of this messages last week. Would you like to receive the same message again in the future?" The percentage of customers who reported that they would like to receive the message again was $80 \%$ both for those who had received a placebo reminder and those who had received one of the variations of the moral message. The fact that a large majority of customers would like to receive a similar message again suggests that receiving a moral appeal does not create a disutility to the recipients. Moreover, receiving a message containing a moral appeal does not seem to create a differential disutility, compared to a simple reminder.

As an additional test, we also examine whether sending a moral appeal negatively affects the bank by reducing card usage or transaction volumes (perhaps because customers are dissatisfied with the bank after receiving the message or want to avoid receiving a similar message in the future). We find that this is not the case. In the 30-day window after the intervention, the average

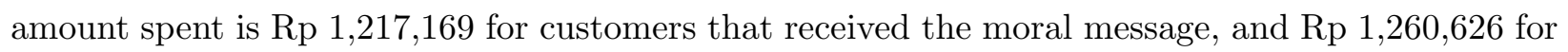

\footnotetext{
${ }^{39}$ We also obtained the repayment history of all clients in our sample from the partner bank, and use this information to test whether the response to the moral incentive treatment differs, depending on whether a customer appears on the list of late payers for the first time or has been delinquent before. We find no evidence that this is the case.

${ }^{40}$ These findings also relate to those in Hallsworth et al. (2015), where a reframing of debt non-repayment from an error of "omission" to an error of "commission" increased of repayment of tax debt. The authors in that paper also find that the act of commission is associated with greater beliefs about punishment for non-repayment, and this change in beliefs about punishment is their preferred interpretation for their results. In our setting, since there are no changes in beliefs about punishment from the bank, the findings indicate an association of commission with greater moral costs. This suggests that the mechanism of moral penalties might also be at play, in addition to the main channel proposed in that paper.
} 
customers in the control group ( $\mathrm{p}$-value $=0.699$ ). The probability of card usage during this time period is .448 and .441 respectively $(\mathrm{p}$-value $=0.691) .{ }^{41}$

\section{Interpreting the Results}

\subsection{What Drives the Moral Appeal}

The evidence from the previous section rules out several mechanisms that are unrelated to moral suasion but could generate higher repayment rates in response to the moral message. We now explore competing hypotheses for the effectiveness of the moral appeal and present tests to distinguish between these alternative explanations.

\subsubsection{Religious Connotation of the Message?}

The first possibility is that the moral message only reduces delinquency because it is delivered in a religious context. This seems plausible, since the original moral incentive message explicitly quoted the Prophet and cited the religious text from which the quote was taken. Moreover, the original moral incentive message used a word for "injustice" that is of Arabic origin and that is often used in a religious context.

In order to distinguish the religious context of the moral message from the effect of the moral appeal, the bank sent two additional variations of the moral message to a randomly chosen subset of credit card customers. The first message was identical to the main treatment, but omitted the reference to the Prophet and the source of the quote. The second variation of the moral message omitted the reference to the Prophet, the source of the quote, and replaced the Arabic-origin word for "injustice" with the standard Indonesian word, which has no religious connotation. Hence, the first message tests whether adding a credible religious source adds power to the impact of a moral appeal. The second message tests if receiving a simple moral appeal without any religious connotation can also affect the repayment decision.

The results are reported in regression format in Table 6 . The three versions of the moral message had very similar effects on raw delinquency in the months in which they were sent (4.1 percentage points for the religious moral message and 3.9 points for the other two versions). Fisher exact p-values for the null hypothesis of no effect against the religious moral message are 0.929 for the non-religious moral message and 0.964 for the implicit moral message (while Fisher exact p-value against the control group are 0.043 and 0.040 , respectively). ${ }^{42}$ This could indicate that either customers already associated the moral appeal contained in the message with religion (and potentially with the Prophet), or that the pure moral statement was sufficient to reduce delinquency.

\footnotetext{
${ }^{41}$ These results also hold for different time windows after receiving the message.

${ }^{42}$ The $95 \%$ confidence intervals for the ratio between the coefficient of the non-religious and the implicit versions on the effect of the religious versions of the message are respectively $[0.109 ; 1.400]$ and $[0.111 ; 1.435]$.
} 
To disentangle these competing hypotheses, we conducted a follow-up phone survey with a random sample of credit card customers. In this phone survey, the message with the standard Indonesian word for "injustice" and without reference to the Prophet was read to customers, who were then asked to indicate its source. ${ }^{43}$ The vast majority of clients were not immediately aware of the religious origin of the message. When asked "Who do you think might have said this phrase?", out of 5 given options, $77 \%$ chose "I don't know", whereas only $19 \%$ associated the phrase with religious figures or institutions (including the bank itself). These findings suggest that the lower delinquency was not due to an implicit religious association with the message. These results also corroborate the view that our sample is relatively secular; most clients did not recognize the Islamic doctrine on non-repayment of debts.

The follow-up survey helps us further clarify the role of religiosity in explaining the effects. In the survey, respondents were asked about the importance of religion and the rules of Islamic law in their life, using a 1-5 Likert scale. The survey also asked customers to rank the relative importance of family, work, friends and religion. Because of the small sample size of the survey, we cannot directly use this measure to assess the individual-level heterogeneity of treatment effects. ${ }^{44}$ Instead, we use it to construct province-level indicators of religiosity. To do so, we split the sample according to the share of respondents who identified as very religious in each province and compare treatment effects for customers in locations classified as more or less religious according to this measure. ${ }^{45}$ For provinces below the median in terms of religiosity, receiving some version of the moral message reduced delinquency by 3.8 percentage points ( $\mathrm{p}$-value $=0.003$ ). For provinces in the top half in terms of religiosity, receiving some version of the moral message had a significantly higher effect, with an additional 4.7 percentage point decrease in the likelihood of becoming delinquent. The p-value of the interaction between the moral message and a dummy for local religiosity above the median is 0.047. ${ }^{46}$ Interestingly, these patterns are similar for the religious, implicit, and nonreligious version of the moral message. This suggests that customers in more religious regions may be more responsive to moral appeals in general. Taken together, these findings indicate that our main effects are driven by the response to the moral appeal rather than the religious nature of the message, although it is possible that the religious context of our experiment enhances the responsiveness of clients to these moral appeals.

\footnotetext{
${ }^{43}$ None of the customers in this sample had previously received any of the moral incentive text messages.

${ }^{44}$ This survey was administered to 2,840 customers. Among them 2,273 participants of our experiment and 567 randomly selected customers of the bank that did not participate in the experiment.

${ }^{45}$ Customers are identified as very religious if they answered "Extremely Important" to both the question about religion and the question about the rules of Sharia law, and if they ranked religion as the most important thing in their life among all the choices given.

${ }^{46}$ We find the same result using data from the Indonesian Family Life Survey (IFLS). Using responses to the question "How religious are you?" we built a similar measure of local religiosity and ranked provinces with respect to the proportion of respondents who describe themselves as "very religious". The results are quite similar: the moral message leads to a 3 percentage point increase in repayment in the less religious half of provinces $(p$-value=0.104), and and additional 3 percentage point increase in the more religious half of provinces. The p-value of the interaction between the moral incentive treatment and a dummy for local religiosity above the median is 0.131 .
} 


\subsubsection{Provision of New Information? The Impact of Repeated Messages}

We also explore whether the moral message only works on the first time it is sent-for example, because it conveys new information — or if it continues to work when the message is sent to customers who have received it before. To address this question, we conducted a follow-up experiment with a sample of customers who had already received the moral message once and re-appeared on the list of late payers. In February and April 2016, customers in this group were either sent the same version of the moral message that they had previously received for a second time, with a lag of either two months or approximately one year, or were assigned to a control group that received no additional message.

Table 7 reports the results, pooling across different versions of the moral incentive messages. We find suggestive evidence that repeated moral messages still affect repayment, and that the size of the effect is not lower among customers to whom the moral message is sent for a second time. In the specification without individual covariates and month fixed effects, reported in Table 7, column (1), the effect of the repeated moral message is 4.1 percentage points ( $\mathrm{p}$-value $=0.175$, Fisher exact p-value $=0.159) \cdot{ }^{47}$

Next, we compare the effects of the first and the second moral messages. In order to do so, we pool the sample from the repeated message experiment with the data from the main experiment. This requires some caution, since there are likely to be selection issues. In particular, customers who show up on the list of late payers for a second time are likely to be different from those who appear on the list for the first time. Indeed, we find that while the two samples are well balanced on demographics, customers in the repeated message sample have lower income and credit limits, and are more likely to have been more than thirty day past due at least once in the previous year. ${ }^{48}$ For this reason, it is important to include individual covariates to address this potential selection problem. ${ }^{49}$ The results are reported in Table 7 , column (4). The point estimate of receiving the moral message for the first time is 4.5 percentage points. With a point estimate of 4.3 percentage points, the effect of receiving the moral message for a second time is nearly identical, and both effects are statistically significant. The p-value of a test of equality of the two effects is 0.955 , and

\footnotetext{
${ }^{47}$ There is suggestive evidence that the effects do not vary depending on the time lag between the first and the repeated message. Sending the moral message to customers who already received the same message one year before increases repayment by 4.0 percentage points compared to sending no message ( $p$-value=0.323). Sending a moral message to customers who received the same message two months before increases repayment by 4.4 percentage points compared to sending no message $(\mathrm{p}$-value $=0.346)$. However, the sample sizes are too small to estimate effects separately by time since the first message.

${ }^{48}$ See Appendix Table A.5 for details.

${ }^{49}$ Another possible concern is the presence of differential selection due to the treatment. However, we do not find any evidence of this type of selection: the proportion of customers showing up on the list of late payers a second time in 2016 after having appeared in the sample of our main experiment in 2015 is 0.251 among those receiving a moral message and 0.242 among controls ( $p$-value of the difference 0.345 ). So, the fact of being late again after a few months from our intervention is likely due to some negative shock independent of treatment status (possibly a negative income or liquidity shock, which is in line with these customers having lower income, credit limit and being more likely to have been more than 30 days past due in the past).
} 
the $95 \%$ confidence interval of the ratio between the effect the second time and the effect the first time is $[-0.156 ; 2.092] .50$

The result that the moral message affects repayment even when it is sent repeatedly rules out the possibility that the message affects repayment by conveying new information. In addition, the finding that even a moral message with no reference to religion affects repayments indicates that the effect is not driven by the recipient learning about a religious teaching that they were not previously aware of. Similarly, the effect cannot be explained by the customer learning that non-repayment of debts can be considered immoral. In both cases, the message would affect repayment only when this information is conveyed to a delinquent customer for the first time. While we cannot test for this directly, our results are consistent with an interpretation according to which consumers care about the morality of repaying their debt, and the moral incentive message temporarily draws their attention to the moral aspect of the repayment decision.

\subsection{Additional Results and Extensions}

\subsubsection{Impact on Default}

In this section, we examine the effect of the moral message on default, defined as failing to make a payment within 90 days of the repayment deadline. Since the financial product we consider is a revolving line of credit, customers face strong repayment incentives. It is therefore not surprising that outright default is a rare event, and much less common than delinquency: in our sample, only $5 \%$ of customers eventually end up defaulting on their credit card debt. ${ }^{51}$ Table 8 , columns (7) and (8) show that the moral incentive message does not reduce this already very low default rate when we consider the entire population of experimental participants. However, there is substantial variation in the ex-ante credit risk of customers in this sample and we find that the moral message is extremely effective at reducing default among the customers with the highest ex-ante credit risk. To calculate a customer's ex-ante credit risk, we estimate a linear model of default probabilities for customers in the control group. More specifically, we run a linear regression of a dummy variable for whether a customer defaulted on month fixed effects and a set of individual-level covariates. We then use the model to predict the credit risk for each customer and split the sample into groups according to the predicted probability of default. Columns (9) and (10) of Table 8 restrict the sample to the $10 \%$ of customers with the highest predicted credit risk. In column (9) we look at raw default rates and find that the moral incentive message decreases the probability of default by 10.5 percentage points from a baseline default rate of $13 \%$ (Fisher exact p-value=0.015).

\footnotetext{
${ }^{50}$ Note that here we are attempting to compare the size of the effect of a message sent to customers who have never seen it before and are late for a first time, to the size of the effect in the (selected) sample of customers who have seen the message before and are late a second time. While both estimates can be interpreted causally, we cannot causally evaluate the effect of repeated messages on the non-selected sample since no further messages are sent to customers who are not late a second time.

${ }^{51}$ Information about default is available only for customers in the first three waves of our experiment.
} 
Reputational incentives are also effective in reducing default among high risk customers: informing customers about the credit registry decreases the probability of default by 7.7 percentage points (Fisher exact p-value=0.017). The results remain similar in column (10), where we add month fixed effects and covariates. ${ }^{52}$

\subsubsection{Impact on the Intensive Margin of Repayment}

We can further unpack the mechanism through which moral incentives affect behavior by examining the intensive margin of repayment, that is, the amount repaid conditional on meeting the minimum payment. Since each of our treatments may induce a different subset of consumers to repay, looking at the intensive margin of repayment in isolation induces selection problems. In fact, because customers with a lower average willingness to repay might make a payment if they were included in one of the moral incentive treatment groups, a simple comparison between treatment and control groups would most likely understate the intensive margin effect.

To avoid this selection problem, we impute zeros for all customers who did not make a payment and analyze the combined effect of our treatments on the intensive and extensive margin. These are unconditional means, and therefore not subject to selection. The average amount repaid in the control group is $\mathrm{Rp} 637,819$, and the expected repayment in the moral incentive group is slightly higher than in the reputational incentive group at $\mathrm{Rp} 745,352$ versus $\mathrm{Rp} 713,437$ (p-value=0.654). ${ }^{53}$ The share of customers that repay substantially more than, i.e. more than twice, the amount required to avoid being reported to the credit registry is significantly higher in the moral incentive group, compared to the reputational message group ( $23 \%$ versus $19 \%$, p-value $=0.096)$. This result suggests that customers in the reputational incentive treatment act much more strategically in response to the message and are more likely to repay only the required $10 \%$ of their outstanding balance. In contrast, customers receiving the moral message tend to repay more than the amount needed to avoid being reported to the credit registry.

\footnotetext{
${ }^{52}$ We find that moral and reputational incentives also decreases delinquency by respectively 13.7 and and 18.6 percentage points in this high-risk group (see columns (3) and (4) of Table 8): this implies that the messages reduce defaults by increasing immediate repayment by the end of grace period deadline, that is, during the time period when we have full experimental control, and not by changing behavior afterwards, when the treatments could potentially interact with external factors. Table 8 reports additional results on both delinquency and default across all treatments available, including for customers with low credit risk. In Supplementary Appendix Table A.6, we report results for different credit risk cutoffs and show that the moral message leads to economically meaningful and statistically significant reductions for various alternative sub-samples of customers with above-median credit risk. When we expand the sample to the $25 \%$ of customers with the highest ex-ante credit risk, we find that the moral message reduces default by $4.3 \%$ (from a baseline default rate of $11 \%$ ). In the sample of customers with above-median ex-ante credit risk, we still find a marginally significant reduction in defaults of 2.2 percentage points (from a baseline default rate of $8 \%$ ). To further verify these results, we also predict the ex-ante credit risk of customers in our sample using two different machine learning algorithms. The results of these exercises are reported in Table A.7 and Table A.8 in the Supplementary Appendix.

${ }^{53}$ For these comparisons, we restrict the sample to customers late in February, March and May 2015 since there are the only months when the reputational incentive message was sent. If we consider the whole sample, the average amount repaid in the control group is $\mathrm{Rp} 615,835$ and in the moral incentive group is $\mathrm{Rp} 725,169$.
} 
Therefore, while the reputational message has a larger effect on the extensive margin than the moral incentive, it has a smaller effect on the intensive margin of repayment. There are two possible channels at play: moral hazard and adverse selection. With moral hazard, ex-ante identical individuals will respond differently to each message. For example, after receiving a message stating that the bank reports all customers who fail to meet the minimum payment to the credit registry, an individual may exert effort to meet the minimum payment (but will not make a payment exceeding this amount). On the other hand, that same individual may decide to repay even more than the required minimum amount after being reminded of the injustice of failing to repay her debt. In the presence of adverse selection, individuals who respond to each message are different ex-ante. For example, customers who respond to the threat of being reported to a credit registry may be more strategic to begin with. ${ }^{54}$ Since meeting the minimum repayment is voluntary, we cannot disentangle moral hazard from adverse selection in our setting. Note, however, that while moral hazard and adverse selection have different welfare implications, they have the same implication for the effectiveness of moral and material incentives in our setting: while material incentives are effective in inducing people to meet the minimum payment, few people pay more than the minimum. In contrast, moral incentives induce slightly fewer people to meet the minimum repayment. However, more of those who repay exceed the minimum required amount.

\subsubsection{Impact on Savings Account Balances}

To better understand how customers make payments in response to the experimental treatments, we next examine the effect of repayment on savings account balances. For this purpose, we obtained detailed data on savings account balances for participants of our experiment from our partner bank. We have access to customers' daily balances on their tabungan (Indonesian for "savings") accounts. These are the most common type of deposit account among clients of our partner bank, and have all characteristics of a standard liquid savings account. Since credit credit card customers are not required to also have another account with the bank, savings account balances are available for only $13 \%$ of customers in our sample, which may give rise to selection issues.

We find that meeting the minimum payment increases the likelihood of a reduction in customers' savings account balances, suggesting that customers are using their savings account balances to repay more expensive credit card debt. More specifically, among those who met their minimum repayments in response to receiving one of our messages, $22 \%$ reduced their savings account balance between the sixteenth and eighteenth day of the month. Among those who did not repay, only $8 \%$ had a reduction of their savings account balance over the same time period. The difference is significant at the 1 percent level ( $\mathrm{p}$-value $<0.001$ ). However, we do not have sufficient statistical power to detect differences in savings balances across the treatment arms of our intervention, so that we consider this evidence as merely suggestive.

\footnotetext{
${ }^{54}$ See, for example, Einav et al. (2013) for evidence of such "selection on moral hazard" in health insurance.
} 


\section{Conclusion}

In this paper, we provide evidence that non-pecuniary moral incentives affect debt repayment. In our setting, moral appeals are more effective than substantial monetary incentives as a means to encourage debt repayment at different time horizons. We find that the impact of our intervention on behavior is driven by responses to the moral appeal, rather than its religious connotation, and use a number of placebo treatments to rule out competing explanations, such as reminder effects, novelty of the message, priming religion, signaling the lender's commitment to debt collection, and the provision of new information.

An important feature of our experiment is that we are able to shed light on private, individual motivations, as opposed to social image concerns, as drivers of moral behavior. While it is of course difficult to fully rule out the presence of social factors in the repayment decision, we provide evidence that individuals respond strongly to messages directed at their sense of morality, even in a setting where the moral appeal is made in private, so that the peer effects and threats of social shaming that are present in many similar environments (see, for example, DellaVigna et al., 2012; Perez-Truglia and Troiano, 2016) are largely absent. We show that it is possible to activate this individual sense of morality in economic transactions without threats of punishment, or references to the negative consequences of non-repayment, and that this has economically large effects on debt repayment. In addition, we show that the effect of moral appeals in our experiment is not reliant on an explicit association with religion or another moral authority: we find that moral appeals are effective even when any religious connotation is removed and the message simply states that non-repayment of debts violates a moral norm.

While our experiment is set in the context of Islamic banking to obtain an environment where moral appeals are natural and credible, we believe we can derive more general lessons from our findings. Indonesia is a large emerging market economy, in which the product we study is marketed to a relatively secular customer population and widely used across many segments of society. This is reflected in the characteristics of our sample: a customer survey indicates that more than half of the customers at our partner bank have at least one other credit card from a non-Islamic bank, the vast majority of respondents were not aware of the religious origin of the quote used in our messages, and the share of non-Muslims in our sample is very similar to that in the Indonesian population. Moreover, we show that moral appeals are also effective in less religious regions, and that their effect does not rely on an explicit reference to religion. When we restrict the sample to customers in Jakarta, who are much less likely to consider themselves religious, we find effects of a magnitude similar to the rest of the sample. We also test the responsiveness of customers in our sample to monetary incentives using the credit reputation message, and find that the magnitude of their response to this type of incentive is very much in line with findings from credit card customers in other emerging economies (see Liberman, 2016). 
Overall, our findings are consistent with the interpretation that people experience a utility cost from consciously violating a moral norm, even if the act of non-compliance is not observable to others. While this perceived cost may be higher among religious respondents, our results suggest that moral considerations in economic transactions are a more general phenomenon that is likely to extrapolate to populations outside our setting. This provides a partial rationale for the widespread commercial use of moral appeals that highlight a moral norm but make no reference to the negative consequences of non-compliance in many non-religious settings, such as energy conservation, recycling, and loan repayment.

The presence of moral considerations in economic transactions also has important implications for market efficiency, as we show in the Supplementary Appendix. ${ }^{55}$ Introducing a moral disutility of not repaying debt into models of credit provision with adverse selection alleviates the lemons problem, since borrowers with a low ability to repay are more likely to experience a disutility from non-repayment. Moral considerations may additionally alleviate moral hazard in credit markets by making debtors less willing to default. In fact, a theoretical literature on general equilibrium models of default assumes that individuals experience a disutility from default to obtain the existence of a competitive equilibrium with trade (see, for example, Dubey et al., 2005). In these models, efficiency is typically the highest for intermediate costs of debt non-repayment.

The relative importance of monetary and non-monetary considerations in economic decisions is of course context-dependent. Studying how moral incentives operate in other settings is therefore an important avenue for future research.

\footnotetext{
${ }^{55}$ In other contexts, moral considerations can determine the actual existence of markets which transactions are considered repugnant even if the parties directly involved benefit from that trade (see Elias et al., 2016).
} 


\section{References}

Agarwal, Sumit, John C. Driscoll, Xavier Gabaix, and David Laibson, "The Age of Reason: Financial Decisions over the Lifecycle with Implications for Regulation," Brookings Papers on Economic Activity, 2009, 3, 51-117.

_, Paige Martha Skiba, and Jeremy Tobacman, "Payday Loans and Credit Cards: New Liquidity and Credit Scoring Puzzles," American Economic Review, 2009, 99 (2), 412-417.

Akerlof, George A. and Rachel E. Kranton, "Economics and Identity," Quarterly Journal of Economics, 2000, 115, 715-753.

Barro, Robert J. and Rachel M. McCleary, "Religion and Economy," Journal of Economic Perspectives, 2006, 20 (1), 49-72.

Bénabou, Roland and Jean Tirole, "Intrinsic and Extrinsic Motivation," Review of Economic Studies, 2003, 70 (3), 489-520.

_ and _, "Incentives and Prosocial Behavior," American Economic Review, 2006, 96 (5), 16521678 .

_ , Davide Ticchi, and Andrea Vindigni, "Forbidden Fruits: The Political Economy of Science, Religion, and Growth," Working Paper, 2015.

Benjamin, Daniel J., James J. Choi, and Geoffrey W. Fisher, "Religious Identity and Economic Behavior," Review of Economic and Statistics, 2016, 98, 637-617.

Bertrand, Marianne and Adair Morse, "Information Disclosure, Cognitive Biases, and Payday Borrowing," Journal of Finance, 2011, 66 (6), 1865-1893.

Bordalo, Pedro, Nicola Gennaioli, and Andrei Shleifer, "Salience and Consumer Choice," Journal of Political Economy, 2013, 121 (5), 803-843.

Cadena, Ximena and Antoinette Schoar, "Remmbering to pay? Reminders vs. financial incentives for loan payments," Working Paper 17020, National Bureau of Economic Research 2011.

Campante, Filipe and David Yanagizawa-Drott, "Does Religion Affect Economic Growth and Happiness? Evidence from Ramadan," Quarterly Journal of Economics, 2015, 130 (2), 615-658.

Cantoni, Davide, "The Economic Effects of the Protestant Reformation: Testing The Weber Hypothesis in The German Lands," Journal of the European Economic Association, 2015, 13 (4), 561-736.

Clingingsmith, David, Asim Ijaz Khwaja, and Michael Kremer, "Estimating the Impact of The Hajj: Religion and Tolerance in Islam's Global Gathering," Quarterly Journal of Economics, 2009, 124 (3), 1133-1170.

Dal Bó, Ernesto and Pedro Dal Bó, "“Do the Right Thing:" The Effects of Moral Suasion on Cooperation," Journal of Public Economics, 2014, 117, 28-38. 
DellaVigna, Stefano and Matthew Gentzkow, "Persuasion: Empirical Evidence," Annual Review of Economics, 2010, 2, 643-669.

_, Ulrike Malmendier, and John A. List, "Testing for Altruism and Social Pressure in Charitable Giving," Quarterly Journal of Economics, 2012, 127, 1-56.

Dubey, Pradeep, John Geanakoplos, and Martin Shubik, "Default and Punishment in General Equilibrium," Econometrica, 2005, 73 (1), 1-37.

Einav, Liran, Amy Finkelstein, Stephen P. Ryan, Paul Schrimpf, and Mark R. Cullen, "Selection on Moral Hazard in Health Insurance," American Economic Review, 2013, 103 (1), $178-219$.

Elias, Julio J., Nicola Lacetera, and Mario Macis, "Efficiency-Morality Trade-Offs in Repugnant Transactions: A Choice Experiment," Working Paper 22632, National Bureau of Economic Research September 2016.

Fellner, Gerlinde, Rupert Sausgruber, and Christian Traxler, "Testing Enforcement Strategies in the Field: Threat, Moral Appeal and Social Information," Journal of the European Economic Association, 2013, 11 (3), 634-660.

Frey, Bruno, Not Just for the Money: An Economic Theory of Personal Motivation, Cheltenham, UK: Edward Elgar, 1997.

Gabaix, Xavier, "A Sparsity-Based Model of Bounded Rationality," Quarterly Journal of Economics, 2014, 129 (4), 1661-1710.

Gneezy, Uri, "Deception: The Role of Consequences," American Economic Review, 2005, 95 (1), 384-394.

Guiso, Luigi, Paola Sapienza, and Luigi Zingales, "The Determinants of Attitudes towards Strategic Default on Mortgages," Journal of Finance, 2013, 68 (4), 1473-1515.

Hallsworth, Michael, John A. List, Robert D. Metcalfe, and Ivo Vlaev, "The Making of Homo Honoratus: From Omission to Commission," Working Paper 21210, National Bureau of Economic Research May 2015.

_ , John List, Robert Metcalfe, and Ivo Vlaev, "The Behavioralist As Tax Collector: Using Natural Field Experiments to Enhance Tax Compliance," Jounal of Public Economics, 2017, $148,14-31$.

Iannaccone, Laurence R, "Introduction to the Economics of Religion," Journal of Economic Literature, 1998, 36 (3), 1465-1495.

Ito, Koichiro, Takanori Ida, and Makoto Tanaka, "The Persistence of Moral Suasion and Economic Incentives: Field Experimental Evidence from Energy Demand," American Economic Journal: Economic Policy, Forthcoming.

Karlan, Dean, Margaret McConnell, Sendhil Mullainathan, and Jonathan Zinman, "Getting to the Top of Mind: How Reminders Increase Saving," Management Science, 2016, 62 (12), 3393-3411. 
_, Melanie Morten, and Jonathan Zinman, "A personal touch in text messaging can imprve microloan repayment," Behaviolar Science and Policy, 2016, 1, 25,31.

Kast, Felipe, Stephan Meier, and Dina Pomeranz, "Saving More in Groups: Field Experimental Evidence from Chile," Working Paper 12-060 2016.

Köszegi, Botond and Adam Szeidl, "A Model of Focusing in Economic Choice," Quarterly Journal of Economics, 2013, 128 (1).

Laurin, Kristin, Azim F. Shariff, Joseph Henrich, and Aaron C. Kay, "Outsourcing punishment to God: beliefs in divine control reduce earthly punishment," Proceedings of the Royal Society of London B: Biological Sciences, 2012, 279 (1741), 3272-3281.

Liberman, Andres, "The Value of a Good Credit Reputation: Evidence from Credit Card Renegotiations," Journal of Financial Economics, 2016, 120 (3), 644-660.

Mazar, Nina, On Amir, and Dan Ariely, "The Dishonesty of Honest People: A Theory of Self-Concept Maintenance," Journal of Marketing Research, 2008, 45 (6), 633-644.

McKay, Ryan, Charles Efferson, Harvey Whitehouse, and Ernst Fehr, "Wrath of God: Religious primes and punishment," Proceedings of the Royal Society B: Biological sciences, 2011, 278 (1713), 1858-1863.

Perez-Truglia, Ricardo and Ugo Troiano, "Shaming Tax Delinquents: Evidence from a Field Experiment in the United States," Working Paper, 2016.

Pichon, Isabelle, Giulio Boccato, and Vassilis Saroglou, "Nonconscious influences of religion on prosociality: a priming study," European Journal of Social Psychology, 2007, 37 (5), 10321045 .

Pruckner, Gerald J. and Rupert Sausgruber, "Honesty on the streets: a field study on newspaper purchasing," Journal of the European Economic Association, 2013, 11 (3), 661-679.

Randolph-Seng, Brandon and Michael E. Nielsen, "Honesty: One Effect of Primed Religious Representations," The International Journal for the Psychology of Religion, 2007, 17 (4), 303315.

Shariff, Azim F. and Ara Norenzayan, "God Is Watching You: Priming God Concepts Increases Prosocial Behavior in an Anonymous Economic Game," Psychological Science, 2007, 18 (9), 803-809.

Stango, Victor and Jonathan Zinman, "Limited and Varying Consumer Attention: Evidence from Shocks to the Salience of Bank Overdraft Fees," Review of Financial Studies, 2014, 27 (4), 990-1030.

World Bank, "Global Financial Development Report: Financial Inclusion," 2014.

Zinman, Johnathan, "Household Debt: Facts, Puzzles, Theories, and Policies," Annual Review of Economics, 2015, 7, 251-276.

Zinman, Jonathan, Sule Alan, Mehmet Cemalclar, and Dean Karlan, "Unshrouding: Evidence from Bank Overdrafts in Turkey," Journal of Finance, 2017, Forthcoming. 


\section{Figures and Tables}

\section{Figure 1: Timeline of Events}

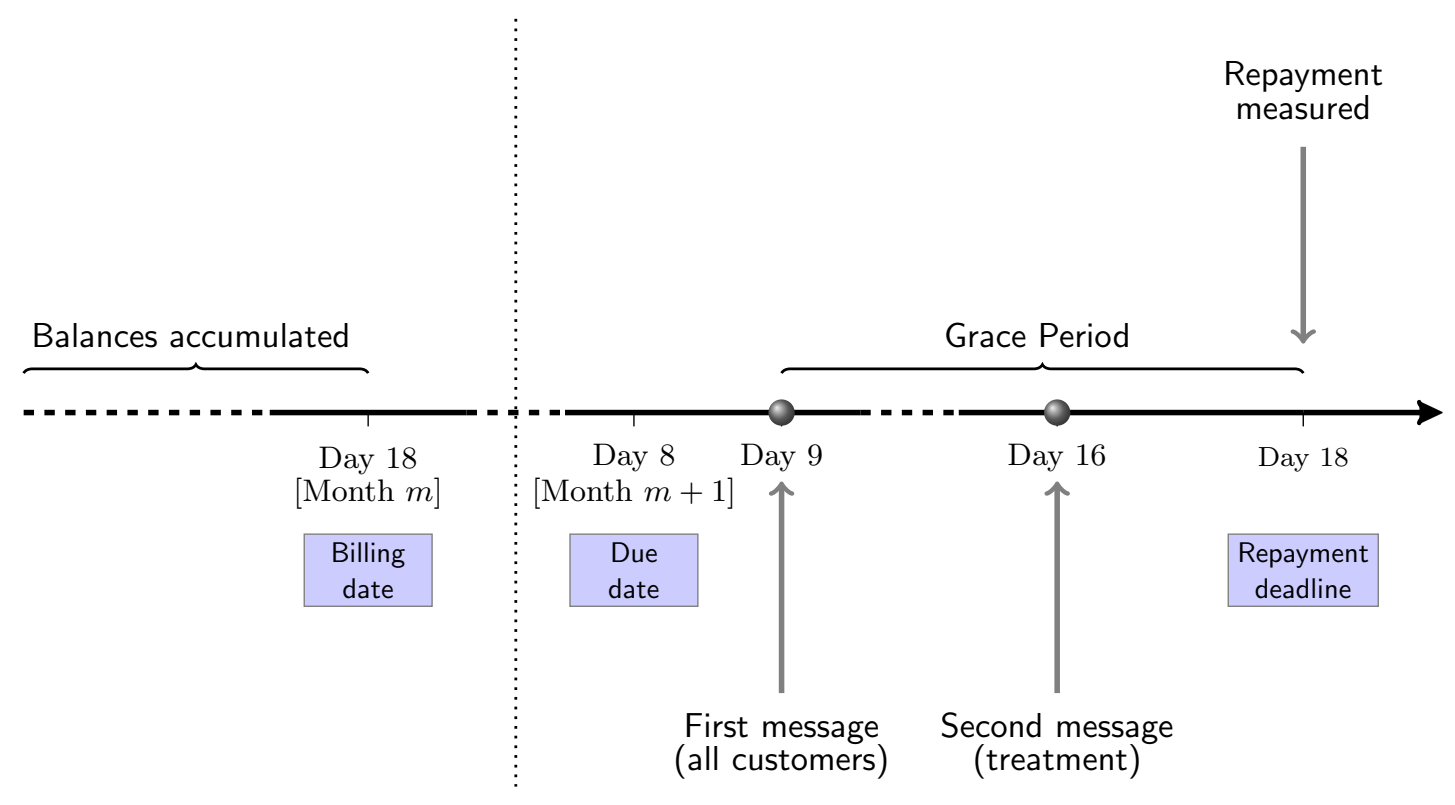

Notes: The figure shows the credit card billing cycle and timing of the intervention. Customers receive their monthly statement on the eigthteenth day of each month. The due date is on the eight day of the following month. One day later, the bank sends a simple reminder message to all late-paying customers. The repayment deadline is on the eighteenth day of the month, at the end of a 10-day grace period. In the morning of the sixteenth day of the month (two days before the repayment deadline), randomly assigned reminder messages are sent to customers assigned to one of the treatment groups. Repayment is observed at the time of the final deadline, which is midnight of the eighteenth day of the month. 
Table 1: Balance and Treatment Cell Size

\begin{tabular}{|c|c|c|c|c|c|c|c|}
\hline \multicolumn{8}{|c|}{ Panel A1: Waves I, II, and III Balance of Covariates } \\
\hline & Full & Moral & Simple & Religious & Credit & Control & $p$-value \\
\hline & Sample & Incentive & Reminder & Placebo & Reputation & Group & \\
\hline & $(1)$ & $(2)$ & $(3)$ & (4) & $(5)$ & $(6)$ & (7) \\
\hline \multirow[t]{2}{*}{ Age } & 42.03 & 42.36 & 42.10 & 41.73 & 41.99 & 42.03 & 0.631 \\
\hline & {$[9.071]$} & {$[9.317]$} & {$[8.776]$} & {$[8.717]$} & {$[9.092]$} & [9.195] & \\
\hline \multirow[t]{2}{*}{ Female } & 0.40 & 0.40 & 0.41 & 0.41 & 0.39 & 0.40 & 0.914 \\
\hline & {$[0.489]$} & {$[0.490]$} & {$[0.491]$} & {$[0.491]$} & {$[0.488]$} & {$[0.489]$} & \\
\hline \multirow[t]{2}{*}{ Muslim } & 0.92 & 0.92 & 0.91 & 0.91 & 0.92 & 0.92 & 0.427 \\
\hline & {$[0.273]$} & {$[0.271]$} & {$[0.286]$} & {$[0.289]$} & {$[0.271]$} & {$[0.264]$} & \\
\hline Annual Income & 151.67 & 135.51 & 185.73 & 134.86 & 177.65 & 132.85 & 0.418 \\
\hline (Rp, million) & [836.968] & [175.295] & [1242.218] & [187.644] & [1369.992] & [201.640] & \\
\hline Credit Limit & 13.55 & 13.93 & 13.28 & 13.77 & 13.38 & 13.55 & 0.438 \\
\hline (Rp, million) & {$[9.338]$} & {$[9.708]$} & [8.652] & {$[9.444]$} & [9.272] & [9.448] & \\
\hline \multicolumn{8}{|c|}{ Panel A2: Waves I, II, and III Treatment Cell Size } \\
\hline Wave I & 2871 & 400 & 400 & 400 & 800 & 871 & \\
\hline Wave II & 2985 & 400 & 400 & 400 & 800 & 985 & \\
\hline Wave III & 1965 & 200 & 200 & 200 & 400 & 965 & \\
\hline Total & 7821 & 1000 & 1000 & 1000 & 2000 & 2821 & \\
\hline \multicolumn{8}{|c|}{ Panel B1: Wave IV Balance of Covariates } \\
\hline & Full & Moral & Moral & Moral & Cash & Control & $p$-value \\
\hline & Sample & Incentive & Incentive & Incentive & Rebate & Group & \\
\hline & & [Religious] & [Implicit] & [Non- & & & \\
\hline & & & & Religious] & & & \\
\hline & $(1)$ & $(2)$ & $(3)$ & (4) & $(5)$ & $(6)$ & (7) \\
\hline \multirow[t]{2}{*}{ Age } & 42.24 & 41.82 & 42.70 & 41.98 & 42.31 & 42.38 & 0.764 \\
\hline & {$[9.491]$} & {$[9.170]$} & {$[9.415]$} & {$[9.137]$} & {$[9.196]$} & {$[10.477]$} & \\
\hline \multirow[t]{2}{*}{ Female } & 0.39 & 0.42 & 0.38 & 0.38 & 0.37 & 0.40 & 0.703 \\
\hline & {$[0.488]$} & {$[0.494]$} & {$[0.486]$} & {$[0.487]$} & {$[0.482]$} & {$[0.490]$} & \\
\hline \multirow[t]{2}{*}{ Muslim } & 0.92 & 0.93 & 0.91 & 0.90 & 0.93 & 0.92 & 0.517 \\
\hline & {$[0.271]$} & {$[0.253]$} & {$[0.281]$} & {$[0.302]$} & {$[0.253]$} & {$[0.265]$} & \\
\hline Annual Income & 134.64 & 121.99 & 132.46 & 138.35 & 152.25 & 128.27 & 0.345 \\
\hline (Rp, million) & [189.589] & {$[192.350]$} & [154.065] & [187.183] & {$[233.037]$} & {$[172.253]$} & \\
\hline Credit Limit & 13.56 & 13.15 & 13.13 & 14.20 & 13.87 & 13.44 & 0.569 \\
\hline (Rp, million) & {$[9.834]$} & {$[10.587]$} & [9.360] & {$[9.525]$} & {$[9.867]$} & {$[9.803]$} & \\
\hline \multicolumn{8}{|c|}{ Panel B2: Wave IV Treatment Cell Size } \\
\hline Wave IV & 1687 & 336 & 336 & 336 & 336 & 343 & \\
\hline \multirow[t]{7}{*}{ Total } & 1687 & 336 & 336 & 336 & 336 & 343 & \\
\hline & & Pan & Wave Var & Balance of & iates & & \\
\hline & Full & Moral & Moral & Moral & Simple & Control & $p$-value \\
\hline & Sample & Incentive & Incentive & Incentive & Reminder & Group & \\
\hline & & [Religious] & [Implicit] & [Non- & & & \\
\hline & & & & Religious] & & & \\
\hline & $(1)$ & $(2)$ & $(3)$ & (4) & $(5)$ & $(6)$ & $(7)$ \\
\hline \multirow[t]{2}{*}{ Age } & 41.61 & 41.73 & 41.80 & 41.36 & 40.95 & 41.79 & 0.557 \\
\hline & {$[9.722]$} & [10.093] & {$[9.481]$} & {$[9.639]$} & {$[9.954]$} & {$[9.562]$} & \\
\hline \multirow[t]{2}{*}{ Female } & 0.39 & 0.41 & 0.37 & 0.40 & 0.43 & 0.36 & 0.087 \\
\hline & {$[0.488]$} & {$[0.492]$} & {$[0.483]$} & {$[0.489]$} & {$[0.496]$} & {$[0.481]$} & \\
\hline \multirow[t]{2}{*}{ Muslim } & 0.90 & 0.88 & 0.90 & 0.92 & 0.88 & 0.89 & 0.087 \\
\hline & {$[0.306]$} & {$[0.326]$} & {$[0.295]$} & {$[0.279]$} & {$[0.321]$} & {$[0.314]$} & \\
\hline Annual Income & 158.51 & 141.85 & 205.76 & 159.15 & 160.08 & 131.45 & 0.379 \\
\hline (Rp, million) & {$[966.064]$} & [556.385] & {$[219.339]$} & [1942.643] & {$[609.755]$} & {$[184.891]$} & \\
\hline Credit Limit & 13.87 & 13.68 & 14.00 & 13.73 & 13.59 & 14.17 & 0.786 \\
\hline (Rp, million) & [10.257] & {$[10.143]$} & [10.037] & {$[10.530]$} & [9.967] & {$[10.441]$} & \\
\hline \multicolumn{8}{|c|}{ Panel C2: Wave V and VI Treatment Cell Size } \\
\hline Wave $\mathrm{V}$ & 2106 & 546 & 482 & 488 & 0 & 590 & \\
\hline Wave VI & 1814 & 362 & 362 & 362 & 362 & 366 & \\
\hline Total & 3920 & 908 & 850 & 844 & 362 & 956 & \\
\hline
\end{tabular}

Notes: Panel A1 reports summary statistics for the sample and presents a test of random assignment for waves I, II, and III. Column (1) reports the mean level of each variable, with standard deviations in brackets, for the full sample. Columns (2) to (6) report the mean level of each variable, with standard deviations in brackets, for all the experimental conditions. Column (7) reports the $p$-value of a test that means are the same in all the experimental conditions. Panel A2 reports treatment cell sizes by month. Panels B1 and B2 replicate this for wave IV. Panels C1 and C2 replicate for waves V and VI. 
Table 2: Moral Incentive Effects

\begin{tabular}{|c|c|c|c|}
\hline Dependent variable & \multicolumn{3}{|c|}{ Dummy for delinquency } \\
\hline & $(1)$ & $(2)$ & $(3)$ \\
\hline Moral Incentive & $\begin{array}{c}-0.044^{* * *} \\
{[0.013]}\end{array}$ & $\begin{array}{c}-0.052^{* * *} \\
{[0.013]}\end{array}$ & $\begin{array}{c}-0.051^{* * *} \\
{[0.013]}\end{array}$ \\
\hline Delinquency Rate Control Group & & 0.66 & \\
\hline Month fixed effects & No & Yes & Yes \\
\hline Controls & No & No & Yes \\
\hline Waves & All Waves & Full Sample & Full Sample \\
\hline $\mathrm{N}$ & 6364 & 13428 & 13428 \\
\hline$R^{2}$ & 0.002 & 0.011 & 0.057 \\
\hline
\end{tabular}

Notes: Column (1) restricts the sample to customers assigned to the moral incentive treatment or to the control group. Column (2) and (3) use the whole sample. Columns (1) presents OLS regression of a dummy variable for whether a customer is delinquent (did not make at least the minimum payment before the end of the grace period) on treatment group dummies. The control is the omitted group, for which we report the mean delinquency rate. Column (2) replicates and adds month fixed effects. Column (3) replicates and adds individual covariates (age, gender dummy, Muslim dummy, province dummy, income, a dummy for being in the sample in a previous month, and a dummy for having been more than 30 days past due at least once in the previous 12 months). Robust standard errors in brackets. * significant at 10\%; ** significant at $5 \%$; *** significant at $1 \%$. 


\section{Table 3: Benchmarking Moral Incentives: Cash Rebate}

\begin{tabular}{lccc}
\hline Dependent variable & \multicolumn{3}{c}{ Dummy for delinquency } \\
\hline \multirow{2}{*}{ Moral Incentive } & $(1)$ & $(2)$ & $(3)$ \\
& -0.054 & $-0.052^{* * *}$ & $-0.051^{* * *}$ \\
Cash Rebate & {$[0.036]$} & {$[0.013]$} & {$[0.013]$} \\
& -0.021 & -0.014 & -0.003 \\
& {$[0.035]$} & {$[0.030]$} & {$[0.029]$} \\
Moral Incentive - & & & \\
$\quad$ Cash Rebate & -0.033 & -0.038 & -0.047 \\
& {$[0.036]$} & {$[0.030]$} & {$[0.029]$} \\
Delinquency Rate Control Group & 0.70 & & 0.66 \\
& \multicolumn{3}{c}{} \\
Month fixed effects & No & Yes & Yes \\
Controls & No & No & Yes \\
Waves & Only Wave IV & Full Sample & Full Sample \\
N & 1015 & 13428 & 13428 \\
$R^{2}$ & 0.002 & 0.011 & 0.057 \\
\hline
\end{tabular}

Notes: Column (1) restricts the sample to customers late in June 2015 and assigned to one of the three following groups: moral incentives, financial incentives (this treatment has been run only in Wave IV) and control. Column (2) and (3) use the whole sample. Column (1) presents OLS regression of a dummy variable for whether a customer is delinquent (did not make at least the minimum payment before the end of the grace period) on treatment group dummies. The control is the omitted group, for which we report the mean delinquency rate. Column (2) replicates and adds month fixed effects. Column (3) replicates and adds individual covariates (age, gender dummy, Muslim dummy, province dummy, income, a dummy for being in the sample in a previous month, and a dummy for having been more than 30 days past due at least once in the previous 12 months). "Moral Incentive - Cash Rebate" gives the difference between the coefficient on "Moral Incentive" and the coefficient on "Cash Rebate." Robust standard errors in brackets. * significant at $10 \%$; ** significant at $5 \%$; ** significant at $1 \%$. 
Table 4: Credit Reputation Effects

\begin{tabular}{lccc}
\hline Dependent variable & \multicolumn{3}{c}{ Dummy for delinquency } \\
\hline & $(1)$ & $(2)$ & $(3)$ \\
Moral Incentive & $-0.060^{* * *}$ & $-0.052^{* * *}$ & $-0.051^{* * *}$ \\
& {$[0.018]$} & {$[0.013]$} & {$[0.013]$} \\
Credit Reputation & $-0.098^{* * *}$ & $-0.102^{* * *}$ & $-0.104^{* * *}$ \\
& {$[0.014]$} & {$[0.014]$} & {$[0.013]$} \\
Moral Incentive - & & & \\
$\quad$ Credit Reputation & $0.038^{* *}$ & $0.051^{* *}$ & $0.053^{* * *}$ \\
& {$[0.019]$} & {$[0.016]$} & {$[0.016]$} \\
Delinquency Rate Control Group & & & \\
& & 0.66 & \\
\hline Month fixed effects & & & \\
Controls & No & Yes & Yes \\
Waves & No & No & Yes \\
N & Waves I, II, and III & Full Sample & Full Sample \\
$R^{2}$ & 5821 & 13428 & 13428 \\
\hline Notes: Col & 0.008 & 0.011 & 0.057 \\
\hline
\end{tabular}

Notes: Column (1) restricts the sample to customers late in February, March or May 2015 and assigned to one of the three following groups: moral incentives, reputational incentives (this treatment has not been run in waves IV, V and VI) and control. Column (2) and (3) use the whole sample. Column (1) presents OLS regression of a dummy variable for whether a customer is delinquent (did not make at least the minimum payment before the end of the grace period) on treatment group dummies. The control is the omitted group, for which we report the mean delinquency rate. Column (2) replicates and adds month fixed effects. Column (3) replicates and adds individual covariates (age, gender dummy, Muslim dummy, province dummy, income, a dummy for being in the sample in a previous month, and a dummy for having been more than 30 days past due at least once in the previous 12 months). "Moral Incentive - Credit Reputation" gives the difference between the coefficient on "Moral Incentive" and the coefficient on "Credit Reputation." Robust standard errors in brackets. * significant at $10 \%$;* significant at $5 \%$; *** significant at $1 \%$. 
Table 6: What Drives the Moral Appeal? Religious Connotation

\begin{tabular}{|c|c|c|c|}
\hline \multirow[t]{2}{*}{ Dependent variable } & \multicolumn{3}{|c|}{ Dummy for delinquency } \\
\hline & $(1)$ & $(2)$ & $(3)$ \\
\hline Moral Incentive & $\begin{array}{c}-0.041^{* *} \\
{[0.019]}\end{array}$ & $\begin{array}{c}-0.051^{* * *} \\
{[0.013]}\end{array}$ & $\begin{array}{c}-0.051^{* * *} \\
{[0.013]}\end{array}$ \\
\hline Implicit Moral Incentive & $\begin{array}{c}-0.039^{* *} \\
{[0.019]}\end{array}$ & $-0.041^{* *}$ & $\begin{array}{c}-0.039 * * \\
{[0.018]}\end{array}$ \\
\hline Non-Religious Moral Incentive & $\begin{array}{c}-0.039 * * \\
{[0.019]}\end{array}$ & $\begin{array}{c}-0.040^{* *} \\
{[0.018]}\end{array}$ & $\begin{array}{c}-0.038^{* *} \\
{[0.017]}\end{array}$ \\
\hline $\begin{array}{l}\text { Moral Incentives - } \\
\text { Implicit Moral Incentive }\end{array}$ & $\begin{array}{l}-0.001 \\
{[0.019]}\end{array}$ & $\begin{array}{l}-0.011 \\
{[0.018]}\end{array}$ & $\begin{array}{l}-0.011 \\
{[0.018]}\end{array}$ \\
\hline $\begin{array}{l}\text { Moral Incentives - } \\
\text { Non-Religious Moral Incentive }\end{array}$ & $\begin{array}{l}-0.002 \\
{[0.020]}\end{array}$ & $\begin{array}{l}-0.011 \\
{[0.018]}\end{array}$ & $\begin{array}{l}-0.012 \\
{[0.017]}\end{array}$ \\
\hline Delinquency Rate Control Group & 0.68 & & \\
\hline $\begin{array}{l}\text { Month fixed effects } \\
\text { Controls } \\
\text { Waves } \\
\mathrm{N} \\
R^{2} \\
\end{array}$ & $\begin{array}{c}\text { No } \\
\text { No } \\
\text { Wave IV, V, and VI } \\
4909 \\
0.001\end{array}$ & $\begin{array}{c}\text { Yes } \\
\text { No } \\
\text { Full Sample } \\
13428 \\
0.011\end{array}$ & $\begin{array}{c}\text { Yes } \\
\text { Yes } \\
\text { Full Sample } \\
13428 \\
0.057\end{array}$ \\
\hline $\begin{array}{l}\text { Notes: Column (1) restricts the sa } \\
\text { or April } 2016 \text { and assigned to one } \\
\text { incentives without quoting the Pro } \\
\text { (these last two treatments have b } \\
\text { Column (2) and ( } 3 \text { ) use the whol } \\
\text { a dummy variable for whether a } \\
\text { minimum payment before the end of } \\
\text { control is the omitted group, for w } \\
\text { (2) replicates and adds month fixer } \\
\text { covariates (age, gender dummy, Mu } \\
\text { being in the sample in a previous } \\
\text { days past due at least once in the } \\
\text { Moral Incentive" gives the differeno } \\
\text { the coefficient on "Implicit Moral I } \\
\text { Incentive" gives the difference bet } \\
\text { coefficient on "Non-Religious Mora } \\
\text { significant at } 10 \% \text {; } * * \text { significant at }\end{array}$ & $\begin{array}{l}\text { ple to customers late } \\
\text { the four following gr } \\
\text { het, moral incentives } \\
\text { n run only in Wave } \\
\text { sample. Column (1) } \\
\text { istomer is delinquent } \\
\text { he grace period) on tr } \\
\text { ich we report the mec } \\
\text { effects. Column (3) r } \\
\text { im dummy, province } \\
\text { onth, and a dummy f } \\
\text { revious } 12 \text { months). } \\
\text { between the coefficie } \\
\text { centive." "Moral Ince } \\
\text { een the coefficient on } \\
\text { Incentive." Robust st } \\
\text { \%; *** significant at }\end{array}$ & $\begin{array}{l}\text { in June } 2015 \text {, } \\
\text { ups: moral in } \\
\text { without religi } \\
\text { IV, V, and V } \\
\text { presents OL } \\
\text { (did not ma } \\
\text { eatment group } \\
\text { n delinquency } \\
\text { pplicates and } \\
\text { lummy, incom } \\
\text { h having bees } \\
\text { "Moral Incen } \\
\text { tt on "Moral } \\
\text { ntives - Non-I } \\
\text { "Moral Incer } \\
\text { andard errors } \\
1 \% \text {. }\end{array}$ & $\begin{array}{l}\text { February } 2016 \\
\text { entives, moral } \\
\text { n connotation } \\
\text { and control. } \\
\text { regression of } \\
\text { e at least the } \\
\text { dummies. The } \\
\text { rate. Column } \\
\text { dds individual } \\
\text {, a dummy for } \\
\text { more than } 30 \\
\text { ives - Implicit } \\
\text { centives" and } \\
\text { eligious Moral } \\
\text { ives" and the } \\
\text { in brackets. * }\end{array}$ \\
\hline
\end{tabular}


Table 7: The Effect of Repeated Moral Messages

\begin{tabular}{|c|c|c|c|c|}
\hline \multirow[t]{2}{*}{ Dependent variable } & \multicolumn{4}{|c|}{ Dummy for delinquency } \\
\hline & (1) & $(2)$ & $(3)$ & $(4)$ \\
\hline \multirow{2}{*}{ Repeated Moral Incentive } & -0.041 & -0.041 & -0.036 & $-0.043^{*}$ \\
\hline & {$[0.030]$} & {$[0.030]$} & {$[0.031]$} & {$[0.025]$} \\
\hline \multirow[t]{2}{*}{ First Moral Incentive } & & & & $-0.045^{* * *}$ \\
\hline & & & & {$[0.011]$} \\
\hline \multirow{2}{*}{$\begin{array}{l}\text { Repeated Moral Incentive - } \\
\text { First Moral Incentive }\end{array}$} & & & & 0.001 \\
\hline & & & & {$[0.026]$} \\
\hline Delinquency Rate & & 0.70 & & 0.67 \\
\hline \multicolumn{5}{|l|}{ Control Group } \\
\hline Month fixed effects & No & Yes & Yes & Yes \\
\hline Controls & No & No & Yes & Yes \\
\hline Waves & \multicolumn{3}{|c|}{ Waves V and VI } & Full Sample \\
\hline $\mathrm{N}$ & 898 & 898 & 898 & 14326 \\
\hline$R^{2}$ & 0.002 & 0.006 & 0.071 & 0.056 \\
\hline
\end{tabular}

Notes: Column (1), (2) and (3) restrict the sample to customers part of the follow-up experiment, that is customers late in February 2016 or April 2016 and treated in a previous wave with a moral message. Column (4) uses the whole sample (both the main experiment sample and the follow-up experiment sample). Column (1) presents OLS regression of a dummy variable for whether a customer is delinquent (did not make at least the minimum payment before the end of the grace period) on a dummy for having received one of the three version of the moral message after being treated in a previous wave with the same moral message. The control is the omitted group, for which we report the mean delinquency rate. Column (2) replicates and adds month fixed effects. Column (3) replicates and adds individual covariates (age, gender dummy, Muslim dummy, province dummy, income, a dummy for being in the sample in a previous month, and a dummy for having been more than 30 days past due at least once in the previous 12 months). Column (4) replicates, adds a dummy for having received one of the three version of the moral message for the first time, and other treatment group dummies. "Repeated Moral Incentive - First Moral Incentive" gives the difference between the coefficient on "Repeated Moral Incentive" and the coefficient on "First Moral Incentive." P-value for the test of inequality "Moral Incentive < Cash Rebate" in parenthesis. Robust standard errors in brackets. * significant at $10 \%$; ** significant at $5 \%$; *** significant at $1 \%$. 
Table 8: Effect on Default

\begin{tabular}{|c|c|c|c|c|c|c|c|c|c|c|c|c|}
\hline \multirow{3}{*}{$\begin{array}{l}\text { Dependent variable } \\
\text { Group } \\
\end{array}$} & \multicolumn{6}{|c|}{ Dummy for delinquency } & \multicolumn{6}{|c|}{ Dummy for default in 90 days } \\
\hline & \multicolumn{2}{|c|}{ Full Sample } & \multicolumn{2}{|c|}{ High Credit Risk } & \multicolumn{2}{|c|}{ Low Credit Risk } & \multicolumn{2}{|c|}{ Full Sample } & \multicolumn{2}{|c|}{ High Credit Risk } & \multicolumn{2}{|c|}{ Low Credit Risk } \\
\hline & $(1)$ & $(2)$ & $(3)$ & $(4)$ & $(5)$ & $(6)$ & $(7)$ & $(8)$ & $(9)$ & $(10)$ & $(11)$ & $(12)$ \\
\hline Moral Incentive & $\begin{array}{c}-0.080^{* * *} \\
{[0.020]}\end{array}$ & $\begin{array}{c}-0.087^{* * *} \\
{[0.020]}\end{array}$ & $\begin{array}{c}-0.137^{* *} \\
{[0.061]}\end{array}$ & $\begin{array}{c}-0.167^{* * *} \\
{[0.061]}\end{array}$ & $\begin{array}{c}-0.074^{* * *} \\
{[0.022]}\end{array}$ & $\begin{array}{c}-0.080^{* * *} \\
{[0.021]}\end{array}$ & $\begin{array}{l}-0.004 \\
{[0.008]}\end{array}$ & $\begin{array}{l}-0.003 \\
{[0.008]}\end{array}$ & $\begin{array}{c}-0.105^{* * *} \\
{[0.027]}\end{array}$ & $\begin{array}{c}-0.106^{* * *} \\
{[0.029]}\end{array}$ & $\begin{array}{c}0.008 \\
{[0.009]}\end{array}$ & $\begin{array}{c}0.008 \\
{[0.009]}\end{array}$ \\
\hline Credit Reputation & $\begin{array}{c}-0.118^{* * *} \\
{[0.017]}\end{array}$ & $\begin{array}{c}-0.127^{* * *} \\
{[0.017]}\end{array}$ & $\begin{array}{c}-0.186^{* * *} \\
{[0.052]}\end{array}$ & $\begin{array}{c}-0.192^{* * *} \\
{[0.052]}\end{array}$ & $\begin{array}{c}-0.111^{* * *} \\
{[0.018]}\end{array}$ & $\begin{array}{c}-0.121^{* * *} \\
{[0.018]}\end{array}$ & $\begin{array}{l}-0.002 \\
{[0.007]}\end{array}$ & $\begin{array}{l}-0.002 \\
{[0.007]}\end{array}$ & $\begin{array}{c}-0.077^{* * *} \\
{[0.028]}\end{array}$ & $\begin{array}{c}-0.087^{* * *} \\
{[0.029]}\end{array}$ & $\begin{array}{l}0.006 \\
{[0.007]}\end{array}$ & $\begin{array}{c}0.006 \\
{[0.007]}\end{array}$ \\
\hline Simple Reminder & $\begin{array}{l}-0.026 \\
{[0.020]}\end{array}$ & $\begin{array}{c}-0.034^{*} \\
{[0.020]}\end{array}$ & $\begin{array}{l}-0.081 \\
{[0.061]}\end{array}$ & $\begin{array}{l}-0.082 \\
{[0.060]}\end{array}$ & $\begin{array}{l}-0.020 \\
{[0.021]}\end{array}$ & $\begin{array}{l}-0.029 \\
{[0.021]}\end{array}$ & $\begin{array}{c}0.010 \\
{[0.009]}\end{array}$ & $\begin{array}{c}0.011 \\
{[0.009]}\end{array}$ & $\begin{array}{l}-0.011 \\
{[0.040]}\end{array}$ & $\begin{array}{l}-0.017 \\
{[0.041]}\end{array}$ & $\begin{array}{c}0.013 \\
{[0.009]}\end{array}$ & $\begin{array}{c}0.013 \\
{[0.009]}\end{array}$ \\
\hline Religious Placebo & $\begin{array}{l}-0.022 \\
{[0.020]}\end{array}$ & $\begin{array}{l}-0.032 \\
{[0.020]}\end{array}$ & $\begin{array}{l}-0.010 \\
{[0.057]}\end{array}$ & $\begin{array}{l}-0.019 \\
{[0.055]}\end{array}$ & $\begin{array}{l}-0.025 \\
{[0.021]}\end{array}$ & $\begin{array}{l}-0.035^{*} \\
{[0.021]}\end{array}$ & $\begin{array}{c}0.013 \\
{[0.009]}\end{array}$ & $\begin{array}{c}0.013 \\
{[0.009]}\end{array}$ & $\begin{array}{c}0.005 \\
{[0.040]}\end{array}$ & $\begin{array}{l}-0.003 \\
{[0.042]}\end{array}$ & $\begin{array}{c}0.013 \\
{[0.009]}\end{array}$ & $\begin{array}{c}0.013 \\
{[0.009]}\end{array}$ \\
\hline $\begin{array}{l}\text { Delinquency Rate } \\
\text { Control Group }\end{array}$ & & & & & & & & & & & & \\
\hline $\begin{array}{l}\text { Default Rate } \\
\text { Control Group }\end{array}$ & & & & & & & & & & & & \\
\hline Month fixed effects & No & Yes & No & Yes & No & Yes & No & Yes & No & Yes & No & Yes \\
\hline Controls & No & Yes & No & Yes & No & Yes & No & Yes & No & Yes & No & Yes \\
\hline $\begin{array}{l}\text { Waves } \\
\mathrm{N}\end{array}$ & & & & & & ves I, II, a & III & & & & & \\
\hline$R^{2}$ & 0.010 & 0.080 & 0.028 & 0.121 & 0.009 & 0.078 & 0.001 & 0.016 & 0.021 & 0.057 & 0.001 & 0.014 \\
\hline
\end{tabular}

Notes: Columns (1), (2), (7) and (8) restrict the sample to customers late in February, March and May 2015: this is the sample of customers for which information on default at 90 days from the due date is available. Using customers in the control group, we estimate a model of the probability of default by running an OLS regression of a dummy variable for whether a customer defaulted on month fixed effects and individual covariates (age, gender dummy, Muslim dummy, province dummy, income, a dummy for being in the sample in a previous month, and a dummy for having been more than 30 days past due at least once in the previous 12 months). We use the model to predict the probability of default for each customer, and split the sample in two groups: the first with the $10 \%$ of customers with the highest probability of default (High Credit Risk), and the second with the $90 \%$ of customers with the lowest probability of default (Low Credit Risk). Columns (3), (4), (9), and (10) restrict the sample to customers with a high predicted probability of default, while columns (5), (6), (11), and (12) restrict the sample to customers with a low predicted probability of default. Columns (1), (3), and (5) present OLS regression of a dummy variable for whether a customer is delinquent (did not make at least the minimum payment before the end of the grace period) on treatment group dummies. The control is the omitted group, for which we report the mean delinquency rate. Columns (2), (4), and (6) replicate and add month fixed effects and individual covariates. Columns (7), (9), and (11) present OLS regression of a dummy variable for whether a customer defaulted at 90 days from the due date on treatment group dummies. The control is the omitted group, for which we report the mean default rate. Columns (8), (10), and (12) replicate and add month fixed effects and individual covariates. Robust standard errors in brackets. * significant at $10 \%$; $* *$ significant at $5 \%$; $* * *$ significant at $1 \%$. 


\section{Supplementary Appendix}

\section{Appendix Figures}

Figure A.1: Text Messages

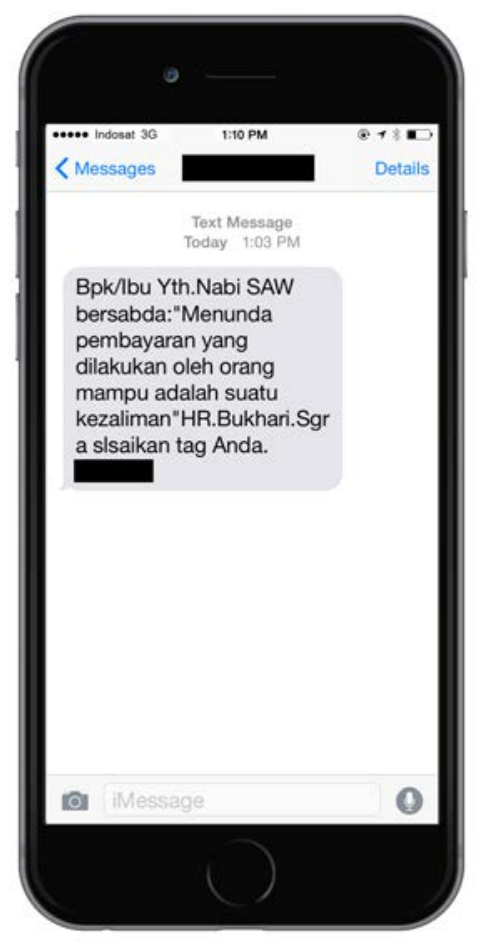

Notes: The figure shows the text message sent to experimental participants assigned to the "moral incentive" treatment condition. 
Figure A.2: Experimental Design
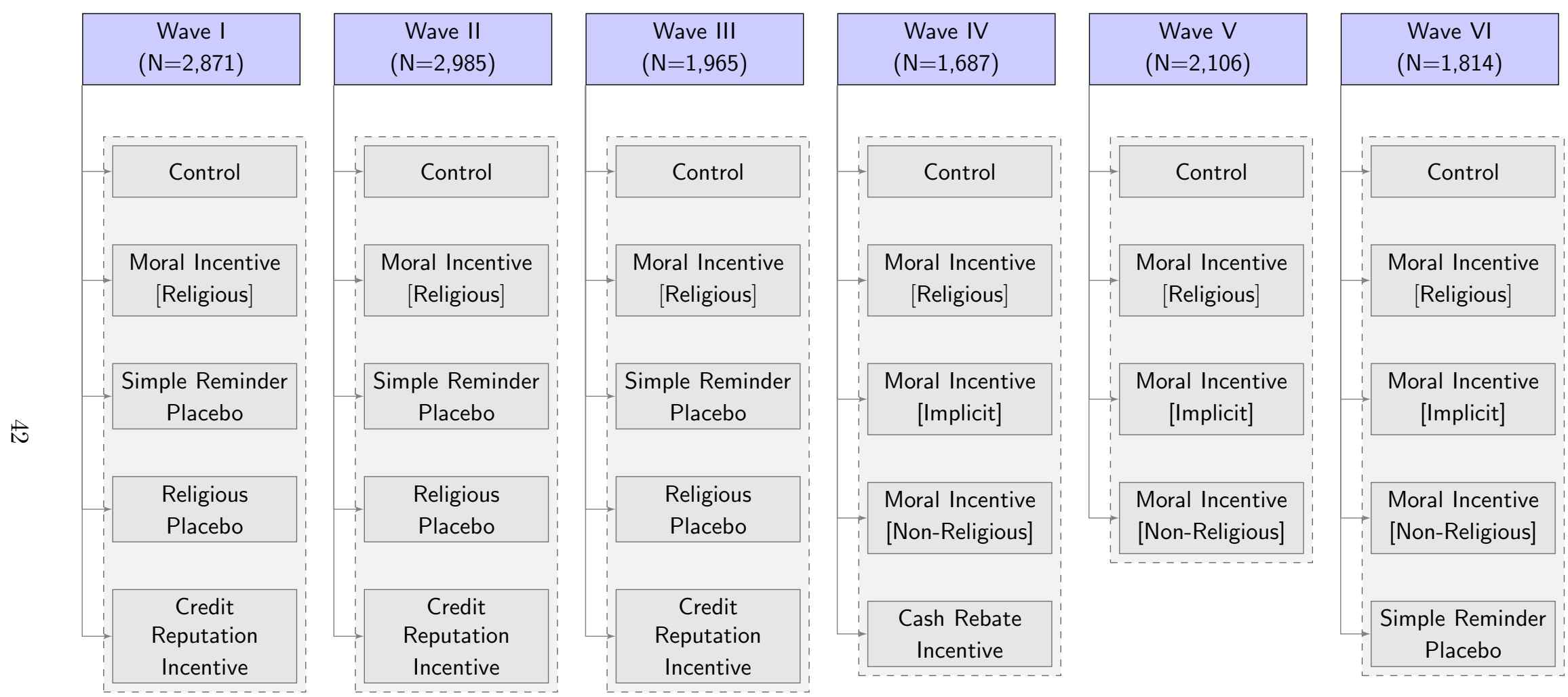

Notes: The figure summarizes the experimental design. The main experiment was conducted in four waves, coinciding with the monthly credit card repayment cycle, between February 2015 and April 2016. Waves I and II were conducted February and March 2015. Waves III and IV were conducted in May and June 2015. A follow-up experiment, consisting of waves V and VI, was conducted in February and April 2016. Within each wave of the experiment, credit card customers that had not made their minimum required payment by the due and were still past-due two days before the end of a ten-day grace period were randomly and individually assigned to the treatment conditions shown in the figure. 


\section{Appendix Tables}

Table A.1: Sample Sizes by Wave

\begin{tabular}{lcccccc}
\hline & $\begin{array}{c}\text { Treated } \\
(1)\end{array}$ & $\begin{array}{c}\text { Control } \\
(2)\end{array}$ & $\begin{array}{c}\text { Repeated } \\
(3)\end{array}$ & $\begin{array}{c}\text { Excluded } \\
(4)\end{array}$ & $\begin{array}{c}\text { Other Project } \\
(5)\end{array}$ & $\begin{array}{c}\text { Total } \\
(6)\end{array}$ \\
\hline Wave I & 2000 & 871 & 0 & 83 & 800 & 3754 \\
Wave II & 2000 & 985 & 0 & 1018 & 800 & 4803 \\
Wave III & 1000 & 965 & 0 & 1823 & 600 & 4388 \\
Wave IV & 1344 & 343 & 0 & 1652 & 0 & 3339 \\
Wave V & 1516 & 590 & 306 & 1075 & 0 & 3487 \\
Wave VI & 1448 & 366 & 592 & 1343 & 0 & 3749 \\
\hline Total & 9308 & 4120 & 898 & 6994 & 2200 & 23520 \\
\hline Notes: Columns (1) & and (2) show the number of customers randomized into \\
treatment and control for the main experiment. Column (3) reports the number \\
of customers who were randomized into treatment and contron for the follow-up \\
experiment on the effect of repeated messages. Column (4) reports the number \\
of customers excluded because they had previously received a text message treat- \\
ment. Customers assigned to the control group in a previous month remained in \\
the sample and could either be assigned to a treatment or be again in the control \\
group. Column (5) reports the number of customers randomized into treatment \\
for a different project. Column (6) reports the total number of late customers.
\end{tabular}


Table A.2: Repeated Message Experiment: Balance and Treatment Cell Size

\begin{tabular}{lcccc}
\hline \multicolumn{5}{c}{ Panel A: Balance of Covariates } \\
& Full & Repeated Moral & Control & $p$-value \\
& Sample & Incentive & Group & \\
& $(1)$ & $(2)$ & $(3)$ & $(4)$ \\
\hline Age & 42.29 & 42.43 & 42.15 & 0.653 \\
& {$[9.375]$} & {$[9.375]$} & {$[9.384]$} & \\
Female & 0.41 & 0.44 & 0.38 & 0.080 \\
& {$[0.492]$} & {$[0.497]$} & {$[0.486]$} & \\
Muslim & 0.90 & 0.91 & 0.89 & 0.321 \\
& {$[0.296]$} & {$[0.282]$} & {$[0.309]$} & \\
Annual Income & 126.72 & 124.07 & 129.35 & 0.702 \\
(Rp, million) & {$[206.906]$} & {$[171.322]$} & {$[237.255]$} & \\
Credit Limit & 13.10 & 13.38 & 12.82 & 0.368 \\
(Rp, million) & {$[9.386]$} & {$[9.445]$} & {$[9.329]$} & \\
\hline \multicolumn{5}{c}{ Panel B: Treatment Cell Size } \\
\hline Wave V & 306 & 153 & 153 & \\
Wave VI & 592 & 295 & 297 & \\
Total & 898 & 448 & 450 & \\
\hline Notes: Pand A & & & \\
\end{tabular}

Notes: Panel A reports summary statistics for the follow-up experiment and presents a test of random assignment. Column (1) reports the mean level of each variable, with standard deviations in brackets, for the full sample. Columns (2) and (3) report the mean level of each variable, with standard deviations in brackets, for the two experimental conditions. Column (4) reports the $p$-value of a test that means are the same in the two experimental conditions. Panel $B$ reports treatment cell sizes by month. 
Table A.3: Heterogeneity of Treatment Effects

\begin{tabular}{lcccccc}
\hline & $(1)$ & $(2)$ & $(3)$ & $(4)$ & $(5)$ & $(6)$ \\
\hline Dependent variable & \multicolumn{5}{c}{ Dummy for delinqency } \\
\hline Trait & Male & Age & Muslim & \multicolumn{2}{c}{ Local } \\
Religiosity & $\begin{array}{c}\text { Debt to } \\
\text { Income Ratio }\end{array}$ & $\begin{array}{c}\text { Poor } \\
\text { Credit History }\end{array}$ \\
\hline \multirow{2}{*}{ Trait*Moral Incentive } & 0.012 & 0.013 & -0.034 & $-0.047^{* *}$ & $0.040^{* *}$ & -0.003 \\
& {$[0.020]$} & {$[0.020]$} & {$[0.035]$} & {$[0.023]$} & {$[0.020]$} & {$[0.024]$} \\
Moral Incentive & $-0.057^{* * *}$ & $-0.056^{* * *}$ & -0.018 & $-0.038^{* * *}$ & $-0.069^{* * *}$ & $-0.049^{* * *}$ \\
& {$[0.017]$} & {$[0.015]$} & {$[0.034]$} & {$[0.013]$} & {$[0.015]$} & {$[0.012]$} \\
Trait & -0.012 & -0.005 & -0.010 & -0.054 & -0.023 & $0.222^{* * *}$ \\
& {$[0.015]$} & {$[0.021]$} & {$[0.026]$} & {$[0.060]$} & {$[0.014]$} & {$[0.017]$} \\
\hline Month fixed effects & Yes & Yes & Yes & Yes & Yes & Yes \\
Controls & Yes & Yes & Yes & Yes & Yes & Yes \\
Waves & All & All & All & All & All & All \\
N & 8,730 & 8,730 & 8,730 & 8,730 & 8,730 & 8,730 \\
$R^{2}$ & 0.050 & 0.050 & 0.050 & 0.050 & 0.050 & 0.050 \\
\hline
\end{tabular}

Notes: The table shows heterogeneous treatment effects for the moral message (all versions). Each column shows results from a separate regression. The dependent variable in all regressions is a dummy for whether a customer is delinquent (did not make at least the minimum payment before the end of the grace period). The dependent variable is regressed on a dummy equal to one if a customer has received any version of the moral incentive treatment, the trait indicated at the top of the table and their interaction. The dummy for age is equal to one for customers with age larger than the median. The dummy for local religiosity is equal to one for customers living in provinces where the measure of local religiosity is higher than the median at the province level. The dummy on debt to income ratio is equal to one for customers with a debt to income ratio larger than the median. The dummy on poor credit history is equal to one for customer reported to the credit registry at least once in the previous six months. ${ }^{*}$ significant at $10 \%$; ${ }^{*}$ significant at $5 \%$; $* * *$ significant at $1 \%$. 
Table A.4: First Three Waves Including Crowding-Out Experiment

\begin{tabular}{lccc}
\hline Dependent variable & \multicolumn{3}{c}{ Dummy for delinquency } \\
\hline Treatments: Main experiment & $(1)$ & $(2)$ & $(3)$ \\
Moral Incentive & $-0.060^{* * *}$ & $-0.065^{* * *}$ & $-0.063^{* * *}$ \\
& {$[0.018]$} & {$[0.018]$} & {$[0.017]$} \\
Simple Reminder & -0.006 & -0.011 & -0.010 \\
& {$[0.018]$} & {$[0.018]$} & {$[0.017]$} \\
Religious Placebo & -0.002 & -0.007 & -0.008 \\
& {$[0.018]$} & {$[0.018]$} & {$[0.017]$} \\
Credit Reputation & $-0.098^{* * *}$ & $-0.103^{* * *}$ & $-0.103^{* * *}$ \\
& {$[0.014]$} & {$[0.014]$} & {$[0.014]$} \\
\hline Treatments: Crowding-out experiment $[$ multiple messages & in one & $d a y]$ & \\
Moral Incentive & $-0.094^{* * *}$ & $-0.099^{* * *}$ & $-0.091^{* * *}$ \\
+ Credit Reputation & {$[0.018]$} & {$[0.018]$} & {$[0.018]$} \\
Simple Reminder & $-0.072^{* * *}$ & $-0.077^{* * *}$ & $-0.075^{* * *}$ \\
+ Due Date Message & {$[0.018]$} & {$[0.018]$} & {$[0.017]$} \\
Delinquency Rate Control Group & 0.66 & 0.66 & 0.66 \\
\hline Month fixed effects & No & Nos & Yes \\
Controls & Waves I, II, and III & Waves I, II, and III & Waves I, II, and III \\
Waves & 9821 & 9821 & 9821 \\
N & 0.008 & 0.018 & 0.076 \\
$R^{2}$ & No & Yes & \\
\hline
\end{tabular}

Notes: Column (1), (2), and (3) restricts the sample to customers late in February, March and May 2015 and includes two groups with customers receiving multiple text messages on the same day ("Due Date Message and Simple Reminder", and "Moral and Reputational Incentives"), in addition to the control group and all other treatments run in those months. Column (1) presents OLS regression of a dummy for whether a customer is delinquent (did not make at least the minimum payment before the end of the grace period) on treatment group dummies. The control is the omitted group, for which we report the mean delinquency rate. Column (2) replicates and adds month fixed effects. Column (3) replicates and adds individual covariates (age, gender, Muslim dummy, province dummy, income, a dummy for being in the sample in a previous month, and a dummy for having been more than 30 days past due at least once in the previous 12 months). $*$ significant at $10 \%$; $* *$ significant at $5 \%$; *** significant at $1 \%$.

Issues with the Crowding-Out Experiment: The setup of this experiment differs from the treatments in this paper in that recipients were sent multiple messages on the same day. The main treatment for the crowding-out experiment involved sending the moral and reputational messages to clients on the 16th day of the month. We find that the effect of receiving the two messages is similar to the effect of receiving the reputational message only. This is consistent with a case of strong crowding-out, but also with a ceiling effect. We are therefore not able to separate these two stories. Before running the intervention, we decided to include another "placebo" group for this second paper: in case the two messages had an effect over and above the effect of the reputational incentive alone, in principle, this could be due to an effect of a receiving any second message on the same day (in addition to the reputational message). Since, however, the moral message had no effect on top the effect from the reputational message, ex post there was no real need for such placebo. In our design, we also had a placebo approach that was not ideal. The correct placebo would have been to send a neutral message in addition to the reputational message. Instead, the treatment implemented was to send two neutral messages on the same day, which complicates the interpretation. Aside from this design issue, there were also problems in the implementation of these treatments. Because the bank did not want to send two identical messages on the same day, one of the messages in the 'same day double reminder' group was a neutral reminder and the other one was the same message customers were used to receiving at the end of the billing cycle. As we later found out, this created confusion among customers who received both of these messages on the same day. Some customers erroneously believed that the bank had changed the billing cycle dates, or that they were at a later point in the billing cycle than was actually the case, since they had also received the standard end-of-billing cycle message. As a result, what we had intended as a placebo cannot really be interpreted as such. Since these treatments were part of a separate experiment and have a number of design and implementation issues, outlined above, these results were not part of our paper and we abandoned the idea of the crowding-out experiment altogether. 
Table A.5: First Time and Repeated Sample

\begin{tabular}{|c|c|c|c|}
\hline \multicolumn{4}{|c|}{ Panel A: Balance of Covariates } \\
\hline & $(1)$ & $(2)$ & $(3)$ \\
\hline & First Message Sample & Repeated Message Sample & $p$-value \\
\hline \multirow[t]{2}{*}{ Age } & 41.93 & 42.29 & 0.267 \\
\hline & {$[9.320]$} & {$[9.375]$} & \\
\hline \multirow[t]{2}{*}{ Female } & 0.39 & 0.41 & 0.382 \\
\hline & {$[0.489]$} & {$[0.492]$} & \\
\hline \multirow[t]{2}{*}{ Muslim } & 0.91 & 0.90 & 0.376 \\
\hline & {$[0.283]$} & {$[0.296]$} & \\
\hline Income & 151.52 & 126.72 & 0.013 \\
\hline (Rp, million) & {$[827.617]$} & {$[206.906]$} & \\
\hline Credit Limit & 13.64 & 13.10 & 0.092 \\
\hline (Rp, million) & {$[9.678]$} & {$[9.386]$} & \\
\hline \multirow[t]{2}{*}{$30 \mathrm{DPD}$ in last year } & 0.29 & 0.39 & 0.000 \\
\hline & {$[0.452]$} & {$[0.488]$} & \\
\hline \multirow[t]{2}{*}{ Late once before } & 0.10 & 1.00 & 0.000 \\
\hline & {$[0.298]$} & {$[0.000]$} & \\
\hline \multicolumn{4}{|c|}{ Panel B: Treatment Cell Size } \\
\hline Wave I & 2871 & 0 & \\
\hline Wave II & 2985 & 0 & \\
\hline Wave III & 1965 & 0 & \\
\hline Wave IV & 1687 & 0 & \\
\hline Wave V & 2106 & 306 & \\
\hline Wave VI & 1814 & 592 & \\
\hline Total & 13428 & 898 & \\
\hline
\end{tabular}

Notes: Panel A reports summary statistics for the follow-up experiment and presents a test of random assignment. Column (1) reports the mean level of each variable, with standard deviations in brackets, for the full sample. Columns (2) and (3) report the mean level of each variable, with standard deviations in brackets, for the two experimental conditions. Column (4) reports the $p$-value of a test that means are the same in the two experimental conditions. Panel B reports sample sizes by month. 
Table A.6: Effect on Default: Robustness Check

\begin{tabular}{|c|c|c|c|c|c|c|c|c|}
\hline \multirow{2}{*}{$\begin{array}{l}\text { Dependent variable } \\
\text { Group }\end{array}$} & \multicolumn{4}{|c|}{ Dummy for delinquency } & \multicolumn{4}{|c|}{ Dummy for default in 90 days } \\
\hline & Top 5 & Top 10 & Top 25 & Top 50 & Top 5 & Top 10 & Top 25 & Top 50 \\
\hline & $(1)$ & $(2)$ & $(3)$ & $(4)$ & $(5)$ & $(6)$ & $(7)$ & $(8)$ \\
\hline \multirow[t]{2}{*}{ Moral Incentives } & $-0.237^{* * *}$ & $-0.167^{* * *}$ & $-0.067^{*}$ & $-0.061^{* *}$ & $-0.109^{* *}$ & $-0.106^{* * *}$ & $-0.043^{* *}$ & $-0.022^{*}$ \\
\hline & {$[0.088]$} & {$[0.061]$} & {$[0.038]$} & {$[0.027]$} & {$[0.048]$} & {$[0.029]$} & {$[0.020]$} & {$[0.013]$} \\
\hline \multirow[t]{2}{*}{ Credit Reputation } & $-0.131^{*}$ & $-0.192^{* * *}$ & $-0.115^{* * *}$ & $-0.072^{* * *}$ & $-0.088^{* *}$ & $-0.087^{* * *}$ & $-0.045^{* * *}$ & -0.014 \\
\hline & {$[0.070]$} & {$[0.052]$} & {$[0.032]$} & {$[0.024]$} & {$[0.042]$} & {$[0.029]$} & {$[0.017]$} & {$[0.011]$} \\
\hline \multirow[t]{2}{*}{ Simple Reminder } & -0.035 & -0.082 & $-0.064^{*}$ & 0.006 & -0.024 & -0.017 & -0.028 & -0.005 \\
\hline & [0.088] & {$[0.060]$} & {$[0.038]$} & {$[0.027]$} & {$[0.064]$} & {$[0.041]$} & {$[0.021]$} & {$[0.014]$} \\
\hline \multirow[t]{2}{*}{ Religious Placebo } & 0.066 & -0.019 & 0.032 & 0.012 & 0.021 & -0.003 & 0.009 & 0.008 \\
\hline & {$[0.070]$} & {$[0.055]$} & {$[0.036]$} & {$[0.027]$} & {$[0.065]$} & {$[0.042]$} & {$[0.025]$} & {$[0.015]$} \\
\hline Delinquency Rate Control Group & 0.76 & 0.74 & 0.72 & 0.68 & & & & \\
\hline Default Rate Control Group & & & & & 0.15 & 0.13 & 0.11 & 0.08 \\
\hline Month fixed effects & Yes & Yes & Yes & Yes & Yes & Yes & Yes & Yes \\
\hline Controls & Yes & Yes & Yes & Yes & Yes & Yes & Yes & Yes \\
\hline Waves & & & & Waves I, I & and III & & & \\
\hline $\mathrm{N}$ & 392 & 782 & 1956 & 3910 & 392 & 782 & 1956 & 3910 \\
\hline$R^{2}$ & 0.137 & 0.121 & 0.104 & 0.087 & 0.056 & 0.057 & 0.021 & 0.015 \\
\hline
\end{tabular}

Notes: Columns (1) to (8) restrict the sample to customers late in February, March and May 2015: this is the sample of customers for which information on default at 90 days from the due date is available. Using customers in the control group, we estimate a model of the probability of default by running an OLS regression of a dummy variable for whether a customer defaulted on month fixed effects and individual covariates (age, gender dummy, Muslim dummy, province dummy, income, a dummy for being in the sample in a previous month, and a dummy for having been more than 30 days past due at least once in the previous 12 months). We use the model to predict the probability of default for each customer, and split the sample in two groups according to the predicted probability of default. Columns (1) and (5) restrict the sample to the $5 \%$ of customers with the highest credit risk (Top 5), columns (2) and (6) to the $10 \%$ of customers with the highest credit risk (Top 10), columns (3) and (7) to the $25 \%$ of customers with the highest credit risk (Top 25), and columns (4) and (8) to the 50\% of customers with the highest credit risk (Top 50). Columns (1) to (4) present OLS regression of a dummy variable for whether a customer is delinquent (did not make at least the minimum payment before the end of the grace period) on treatment group dummies, month fixed effects, and individual covariates. The control is the omitted group, for which we report the mean delinquency rate. Columns (5) to (8) present OLS regression of a dummy variable for whether a customer defaulted at 90 days from the due date on treatment group dummies, month fixed effects, and individual covariates. The control is the omitted group, for which we report the mean default rate. Robust standard errors in brackets. * significant at $10 \%$; ** significant at $5 \%$; *** significant at $1 \%$. 
Table A.7: Effect on Default: Machine Learning I

\begin{tabular}{|c|c|c|c|c|c|c|c|c|}
\hline \multirow{2}{*}{$\begin{array}{l}\text { Dependent variable } \\
\text { Group }\end{array}$} & \multicolumn{4}{|c|}{ Dummy for delinquency } & \multicolumn{4}{|c|}{ Dummy for default in 90 days } \\
\hline & Top 5 & Top 10 & Top 25 & Top 50 & Top 5 & Top 10 & Top 25 & Top 50 \\
\hline & $(1)$ & $(2)$ & $(3)$ & $(4)$ & $(5)$ & $(6)$ & $(7)$ & $(8)$ \\
\hline \multirow[t]{2}{*}{ Moral Incentives } & $-0.188^{* *}$ & $-0.103^{*}$ & $-0.096^{* * *}$ & $-0.072^{* * *}$ & -0.073 & $-0.079^{* *}$ & $-0.055^{* * *}$ & $-0.028^{* *}$ \\
\hline & {$[0.085]$} & {$[0.062]$} & {$[0.037]$} & {$[0.028]$} & {$[0.054]$} & {$[0.036]$} & {$[0.021]$} & {$[0.013]$} \\
\hline \multirow[t]{2}{*}{ Credit Reputation } & $-0.213^{* * *}$ & $-0.133^{* * *}$ & $-0.147^{* * *}$ & $-0.107^{* * *}$ & -0.072 & $-0.060^{*}$ & -0.030 & -0.011 \\
\hline & {$[0.067]$} & {$[0.050]$} & {$[0.032]$} & {$[0.024]$} & {$[0.048]$} & {$[0.032]$} & {$[0.018]$} & {$[0.011]$} \\
\hline \multirow[t]{2}{*}{ Simple Reminder } & -0.100 & -0.103 & $-0.076^{* *}$ & -0.028 & 0.040 & -0.006 & -0.013 & 0.007 \\
\hline & {$[0.083]$} & {$[0.063]$} & {$[0.036]$} & {$[0.028]$} & {$[0.069]$} & {$[0.045]$} & {$[0.023]$} & {$[0.015]$} \\
\hline \multirow[t]{2}{*}{ Religious Placebo } & 0.049 & 0.006 & $-0.075^{* *}$ & -0.029 & 0.064 & -0.006 & -0.018 & 0.012 \\
\hline & {$[0.069]$} & {$[0.055]$} & {$[0.037]$} & {$[0.027]$} & {$[0.068]$} & {$[0.043]$} & {$[0.023]$} & {$[0.015]$} \\
\hline Delinquency Rate Control Group & 0.80 & 0.74 & 0.75 & 0.70 & & & & \\
\hline Default Rate Control Group & & & & & 0.14 & 0.13 & 0.11 & 0.08 \\
\hline Month fixed effects & Yes & Yes & Yes & Yes & Yes & Yes & Yes & Yes \\
\hline Controls & Yes & Yes & Yes & Yes & Yes & Yes & Yes & Yes \\
\hline Waves & & & & Waves I, II, & and III & & & \\
\hline $\mathrm{N}$ & 391 & 779 & 1964 & 3910 & 391 & 779 & 1964 & 3910 \\
\hline$R^{2}$ & 0.176 & 0.131 & 0.104 & 0.098 & 0.083 & 0.048 & 0.028 & 0.017 \\
\hline
\end{tabular}

Notes: Columns (1) to (8) restrict the sample to customers late in February, March and May 2015: this is the sample of customers for which information on default at 90 days from the due date is available. We estimate a model of the probability of default using a machine learning technique. In particular, we train a gradient boosting (GB) classifier model on customers in the control group. The model predicts default probability based on month fixed effects and individual covariates (age, gender dummy, Muslim dummy, province dummy, income, a dummy for being in the sample in a previous month, and a dummy for having been more than 30 days past due at least once in the previous 12 months), along with square and cubic terms of the continuous variables (age and income) and up to three-way interactions between all covariates. The algorithm uses 10-fold cross-validation (CV), re-sampled ten times. We use the model to predict the probability of default for each customer, and split the sample in two groups according to the predicted probability of default. Columns (1) and (5) restrict the sample to the $5 \%$ of customers with the highest credit risk (Top 5), columns (2) and (6) to the $10 \%$ of customers with the highest credit risk (Top 10), columns (3) and (7) to the $25 \%$ of customers with the highest credit risk (Top 25), and columns (4) and (8) to the $50 \%$ of customers with the highest credit risk (Top 50). Columns (1) to (4) present OLS regression of a dummy variable for whether a customer is delinquent (did not make at least the minimum payment before the end of the grace period) on treatment group dummies, month fixed effects, and individual covariates. The control is the omitted group, for which we report the mean delinquency rate. Columns (5) to (8) present OLS regression of a dummy variable for whether a customer defaulted at 90 days from the due date on treatment group dummies, month fixed effects, and individual covariates. The control is the omitted group, for which we report the mean default rate. Robust standard errors in brackets. * significant at $10 \% ; * *$ significant at $5 \% ; * * *$ significant at $1 \%$. 
Table A.8: Effect on Default: Machine Learning II

\begin{tabular}{|c|c|c|c|c|c|c|c|c|}
\hline \multirow{2}{*}{$\begin{array}{l}\text { Dependent variable } \\
\text { Group }\end{array}$} & \multicolumn{4}{|c|}{ Dummy for Delinquency } & \multicolumn{4}{|c|}{ Dummy for default in 90 days } \\
\hline & Top 5 & Top 10 & Top 25 & Top 50 & Top 5 & Top 10 & Top 25 & Top 50 \\
\hline & $(1)$ & $(2)$ & $(3)$ & $(4)$ & $(5)$ & $(6)$ & $(7)$ & $(8)$ \\
\hline \multirow[t]{2}{*}{ Moral Incentives } & $-0.207^{* *}$ & $-0.115^{*}$ & $-0.097^{* *}$ & $-0.075^{* * *}$ & $-0.127^{* *}$ & $-0.104^{* * *}$ & $-0.058^{* * *}$ & $-0.029^{* *}$ \\
\hline & {$[0.095]$} & {$[0.064]$} & {$[0.038]$} & {$[0.028]$} & {$[0.051]$} & {$[0.034]$} & {$[0.020]$} & {$[0.013]$} \\
\hline \multirow[t]{2}{*}{ Credit Reputation } & $-0.170^{* *}$ & $-0.157^{* * *}$ & $-0.140^{* * *}$ & $-0.092^{* * *}$ & $-0.099^{* *}$ & $-0.101^{* * *}$ & $-0.053^{* * *}$ & -0.014 \\
\hline & {$[0.072]$} & {$[0.053]$} & {$[0.032]$} & {$[0.024]$} & {$[0.047]$} & {$[0.031]$} & {$[0.018]$} & {$[0.011]$} \\
\hline \multirow[t]{2}{*}{ Simple Reminder } & -0.053 & -0.080 & $-0.083^{* *}$ & -0.005 & -0.010 & -0.041 & $-0.046^{* *}$ & -0.003 \\
\hline & {$[0.091]$} & {$[0.066]$} & {$[0.038]$} & {$[0.028]$} & {$[0.069]$} & {$[0.045]$} & {$[0.021]$} & {$[0.014]$} \\
\hline \multirow[t]{2}{*}{ Religious Placebo } & 0.087 & 0.007 & -0.002 & -0.006 & 0.055 & -0.020 & -0.018 & 0.013 \\
\hline & {$[0.074]$} & {$[0.059]$} & {$[0.036]$} & {$[0.027]$} & {$[0.071]$} & {$[0.043]$} & {$[0.023]$} & {$[0.015]$} \\
\hline Delinquency Rate Control Group & 0.77 & 0.72 & 0.72 & 0.69 & & & & \\
\hline Default Rate Control Group & & & & & 0.17 & 0.15 & 0.11 & 0.08 \\
\hline Month fixed effects & Yes & Yes & Yes & Yes & Yes & Yes & Yes & Yes \\
\hline Controls & Yes & Yes & Yes & Yes & Yes & Yes & Yes & Yes \\
\hline Waves & & & & Waves I, & , and III & & & \\
\hline $\mathrm{N}$ & 392 & 782 & 1955 & 3910 & 392 & 782 & 1955 & 3910 \\
\hline$R^{2}$ & 0.121 & 0.108 & 0.099 & 0.084 & 0.076 & 0.061 & 0.022 & 0.017 \\
\hline
\end{tabular}

Notes: Columns (1) to (8) restrict the sample to customers late in February, March and May 2015: this is the sample of customers for which information on default at 90 days from the due date is available. We estimate a model of the probability of default using a machine learning technique. In particular, we train a gradient boosting (GB) classifier model on customers in the control group. The model predicts default probability based on month fixed effects and individual covariates (age, gender dummy, Muslim dummy, province dummy, income, a dummy for being in the sample in a previous month, and a dummy for having been more than 30 days past due at least once in the previous 12 months), along with square and cubic terms of the continuous variables (age and income) and up to three-way interactions between all covariates. The algorithm uses decision trees iterated 1500 times, with a learning rate of .01, a fixed Bernoulli distribution, and a minimum number of observations in each terminal node of 30 . We use the model to predict the probability of default for each customer, and split the sample in two groups according to the predicted probability of default. Columns (1) and (5) restrict the sample to the $5 \%$ of customers with the highest credit risk (Top 5), columns (2) and (6) to the $10 \%$ of customers with the highest credit risk (Top 10), columns (3) and (7) to the $25 \%$ of customers with the highest credit risk (Top 25), and columns (4) and (8) to the $50 \%$ of customers with the highest credit risk (Top 50). Columns (1) to (4) present OLS regression of a dummy variable for whether a customer is delinquent (did not make at least the minimum payment before the end of the grace period) on treatment group dummies, month fixed effects, and individual covariates. The control is the omitted group, for which we report the mean delinquency rate. Columns (5) to (8) present OLS regression of a dummy variable for whether a customer defaulted at 90 days from the due date on treatment group dummies, month fixed effects, and individual covariates. The control is the omitted group, for which we report the mean default rate. Robust standard errors in brackets. * significant at $10 \%$; $* *$ significant at $5 \%$; *** significant at $1 \%$. 
Table A.9: Benchmarking Against Other Studies - Persuasion Rates

\begin{tabular}{|c|c|c|c|c|c|c|c|c|}
\hline Paper & $\begin{array}{l}\text { Treatment } \\
\text { Description }\end{array}$ & $\begin{array}{l}\text { Control } \\
\text { Description }\end{array}$ & $\begin{array}{l}\text { Outcome } \\
\text { Description }\end{array}$ & $\begin{array}{l}\text { Sample } \\
\text { Size }\end{array}$ & $\begin{array}{l}\text { Treatment } \\
\text { Outcome }\end{array}$ & $\begin{array}{l}\text { Control } \\
\text { Outcome }\end{array}$ & $\begin{array}{l}\text { Persuasion } \\
\text { Rate }\end{array}$ & $\begin{array}{l}\text { Persuasion Rate } \\
\text { Per Message }\end{array}$ \\
\hline This paper & 1) Unique text message with moral incentives. & No reminder. & $\begin{array}{l}\text { Percentage of customers having } \\
\text { made at least the minimum pay- } \\
\text { ment on their credit card debt } \\
\text { within the repayment deadline. }\end{array}$ & 6364 & $38.19 \%$ & $33.76 \%$ & $6.69 \%$ & $6.69 \%$ \\
\hline \multirow{4}{*}{$\begin{array}{l}\text { Karlan et al. } \\
(2016 \mathrm{~b})\end{array}$} & $\begin{array}{l}\text { 1) Weekly text messages with reminder to repay } \\
\text { loan, mentioning the account officers name and } \\
\text { using a positive framing. }\end{array}$ & \multirow{4}{*}{ No reminders. } & \multirow{4}{*}{$\begin{array}{l}\text { Percentage of clients having repaid } \\
\text { the loan in full } 30 \text { days past } \\
\text { maturity. }\end{array}$} & \multirow{4}{*}{943} & $96.50 \%$ & \multirow{4}{*}{$86.50 \%$} & $74.07 \%$ & $7.41 \%$ \\
\hline & $\begin{array}{l}\text { loan, mentioning the account officers name and } \\
\text { using a negative framing. }\end{array}$ & & & & $91.60 \%$ & & $37.78 \%$ & $3.79 \%$ \\
\hline & $\begin{array}{l}\text { 3) Weekly text messages with reminder to repay } \\
\text { loan, mentioning the clients name and using a } \\
\text { positive framing. }\end{array}$ & & & & $87.90 \%$ & & $10.37 \%$ & $1.04 \%$ \\
\hline & $\begin{array}{l}\text { 4) Weekly text messages with reminder to repay } \\
\text { loan, mentioning the clients name and using a } \\
\text { negative framing. }\end{array}$ & & & & $86.60 \%$ & & $0.74 \%$ & $0.07 \%$ \\
\hline $\begin{array}{l}\text { Cadena and } \\
\text { Schoar (2011) }\end{array}$ & $\begin{array}{l}\text { 1) Monthly text messages with a thank note and } \\
\text { a reminder about importance of paying on time. }\end{array}$ & No reminders. & $\begin{array}{l}\text { Percentage of clients repaying every } \\
\text { installment of the loan in time. }\end{array}$ & 1121 & $42.81 \%$ & $33.81 \%$ & $14.24 \%$ & $2.04 \%$ \\
\hline \multirow{6}{*}{$\begin{array}{l}\text { Hallsworth et } \\
\text { al. (2015) }\end{array}$} & $\begin{array}{l}\text { 1) Letter also pointed out that the tax authority } \\
\text { was attempting to resolve the issue. }\end{array}$ & \multirow{6}{*}{$\begin{array}{l}\text { Original letter with } \\
\text { information about the } \\
\text { size of debt and how } \\
\text { to pay asking to call } \\
\text { the tax authority. }\end{array}$} & \multirow{6}{*}{$\begin{array}{l}\text { Percentage of receivers repaying } \\
\text { their tax debt obligation with the } \\
\text { UK government within } 30 \text { days } \\
\text { after letters have been sent. }\end{array}$} & \multirow{6}{*}{38290} & $13.10 \%$ & & $1.25 \%$ & $1.25 \%$ \\
\hline & $\begin{array}{l}\text { 2) Letter also suggested making a plan to call the } \\
\text { tax authority. }\end{array}$ & & & & $12.80 \%$ & $12.00 \%$ & $0.91 \%$ & $0.91 \%$ \\
\hline & $\begin{array}{l}\text { 3) Letter also provided a summary box of the } \\
\text { main points of the letter. }\end{array}$ & & & & $12.50 \%$ & 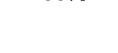 & $0.57 \%$ & $0.57 \%$ \\
\hline & $\begin{array}{l}\text { 4) Letter also provided more information about } \\
\text { call center opening times. }\end{array}$ & & & & $14.20 \%$ & & $2.50 \%$ & $2.50 \%$ \\
\hline & $\begin{array}{l}\text { 5) Letter also stating that lack of response will be } \\
\text { treated as an active choice, and not as an over- } \\
\text { sight (with an individual framing). } \\
\text { 6) Letter also stating that lack of response will be }\end{array}$ & & & & $22.90 \%$ & & $12.39 \%$ & $12.49 \%$ \\
\hline & $\begin{array}{l}\text { treated as an active choice, and not as an over- } \\
\text { sight (with a collective framing). }\end{array}$ & & & & $23.20 \%$ & & $12.73 \%$ & $12.74 \%$ \\
\hline \multirow{5}{*}{$\begin{array}{l}\text { Hallsworth et } \\
\text { al. (2017) }\end{array}$} & $\begin{array}{l}\text { 1) Letter also stating that nine out of ten people } \\
\text { pay takes on time. }\end{array}$ & \multirow{5}{*}{$\begin{array}{l}\text { Original letter with } \\
\text { information about the } \\
\text { size of debt and how } \\
\text { to pay asking to call } \\
\text { the tax authority. }\end{array}$} & \multirow{5}{*}{$\begin{array}{l}\text { Percentage of receivers starting to } \\
\text { pay their tax debt obligation with } \\
\text { the UK government within } 8 \text { days } \\
\text { after letters have been sent. }\end{array}$} & \multirow{5}{*}{98748} & $37.10 \%$ & & $2.02 \%$ & $2.02 \%$ \\
\hline & $\begin{array}{l}\text { 2) Letter also stating that nine out of ten people } \\
\text { in the UK pay takes on time. } \\
\text { 3) Letter also stating that nine out of ten people }\end{array}$ & & & & $37.90 \%$ & $35.80 \%$ & $3.27 \%$ & $3.27 \%$ \\
\hline & $\begin{array}{l}\text { in the UK pay takes on time, and that the tax- } \\
\text { payer is in a small minority of people not having } \\
\text { paid yet. }\end{array}$ & & & & $39.60 \%$ & & $5.92 \%$ & $5.92 \%$ \\
\hline & $\begin{array}{l}\text { 4) Letter also stating that taxes are used for pub- } \\
\text { lic services (gain-framed). }\end{array}$ & & & & $37.40 \%$ & & $2.49 \%$ & $2.49 \%$ \\
\hline & $\begin{array}{l}\text { 5) Letter also stating that taxes are used for pub- } \\
\text { lic services (loss-framed). }\end{array}$ & & & & $37.40 \%$ & & $2.49 \%$ & $2.49 \%$ \\
\hline \multirow{6}{*}{$\begin{array}{l}\text { Fellner et al. } \\
(2013)\end{array}$} & $\begin{array}{l}\text { 1) Baseline letter explaining that the enforcement } \\
\text { authority is legally obliged to clarify why the re- } \\
\text { cipient is not paying the fee. }\end{array}$ & & \multirow{6}{*}{$\begin{array}{l}\text { Percentage of households starting } \\
\text { to pay the annual fee for public } \\
\text { broadcasting withing } 50 \text { days from } \\
\text { the experiment. }\end{array}$} & \multirow{6}{*}{50498} & $7.40 \%$ & & $6.64 \%$ & $6.64 \%$ \\
\hline & $\begin{array}{l}\text { 2) Threat letter also stressing the high detection } \\
\text { risk and increasing the salience of legal and fi- } \\
\text { nancial sanctions. }\end{array}$ & No mail. & & & $8.27 \%$ & $0.81 \%$ & $7.52 \%$ & $7.52 \%$ \\
\hline & $\begin{array}{l}\text { 3) Social information letter also highlighting the } \\
\text { high level of compliance of other households. }\end{array}$ & & & & $7.03 \%$ & & $6.27 \%$ & $6.27 \%$ \\
\hline & $\begin{array}{l}\text { 4) Moral appeal letter also emphasizing that com- } \\
\text { pliance is a matter of fairness. }\end{array}$ & & & & $7.01 \%$ & & $6.25 \%$ & $6.25 \%$ \\
\hline & 5) Threat and social information letter. & & & & $8.33 \%$ & & $7.58 \%$ & $7.58 \%$ \\
\hline & 6) Threat and moral appeal letter. & & & & $7.94 \%$ & & $7.19 \%$ & $7.19 \%$ \\
\hline \multirow{2}{*}{$\begin{array}{l}\text { Pruckner and } \\
\text { Sausgruber } \\
(2013)\end{array}$} & $\begin{array}{l}\text { 1) Message also stating that stealing a paper is } \\
\text { illegal. } \\
\text { 2) Message also thanking the customer for being }\end{array}$ & \multirow{2}{*}{$\begin{array}{l}\text { Publicly displayed sign } \\
\text { with message stating } \\
\text { the cost of a paper. }\end{array}$} & \multirow{2}{*}{$\begin{array}{l}\text { Percentage of customers paying for } \\
\text { the paper in a honor system with } \\
\text { unmonitored payments. }\end{array}$} & \multirow[t]{2}{*}{120} & $36.58 \%$ & \multirow[t]{2}{*}{$32.50 \%$} & $6.04 \%$ & $6.04 \%$ \\
\hline & $\begin{array}{l}\text { 2) Message also thanking the customer for being } \\
\text { honest. }\end{array}$ & & & & $33.33 \%$ & & $1.23 \%$ & $1.23 \%$ \\
\hline $\begin{array}{l}\text { Karlan et al. } \\
(2016 \mathrm{a})\end{array}$ & $\begin{array}{l}\text { 1) Monthly reminders delivered either by text } \\
\text { message (Philippines and Bolivia) or letter } \\
\text { (Peru). }\end{array}$ & No reminders. & $\begin{array}{l}\text { Percentage of clients attaining their } \\
\text { commitment on a commitment sav- } \\
\text { ings account. }\end{array}$ & 13560 & $58.50 \%$ & $55.30 \%$ & $7.16 \%$ & $2.39 \%$ \\
\hline $\begin{array}{l}\text { Kast et al. } \\
(2016)\end{array}$ & $\begin{array}{l}\text { 1) Weekly text messages with information about } \\
\text { saving behavior of peers. } \\
\text { 2) Weekly text messages with reminder that the } \\
\text { customer saving behavior is observable by a peer. }\end{array}$ & No reminders. & $\begin{array}{l}\text { Average number of monthly } \\
\text { deposits in a saving account over a } \\
\text { three month period. }\end{array}$ & 871 & $\begin{array}{l}0.424 \\
0.363\end{array}$ & 0.126 & N/A & N/A \\
\hline
\end{tabular}


Table A.10: Simple Reminder as Comparison Group

\begin{tabular}{|c|c|c|c|c|c|c|}
\hline \multirow{3}{*}{$\begin{array}{l}\text { Dependent variable } \\
\text { Group }\end{array}$} & \multicolumn{3}{|c|}{ Dummy for delinquency } & \multicolumn{3}{|c|}{ Dummy for default in 90 days } \\
\hline & \multicolumn{3}{|c|}{ Full Sample } & \multicolumn{3}{|c|}{ High Credit Risk } \\
\hline & (1) & $(2)$ & $(3)$ & (4) & $(5)$ & $(6)$ \\
\hline Moral Incentive & $\begin{array}{c}-0.054^{* *} \\
{[0.022]}\end{array}$ & $\begin{array}{c}-0.054^{* *} \\
{[0.022]}\end{array}$ & $\begin{array}{c}-0.053^{* *} \\
{[0.021]}\end{array}$ & $\begin{array}{c}-0.094^{* *} \\
{[0.037]}\end{array}$ & $\begin{array}{c}-0.093^{* *} \\
{[0.037]}\end{array}$ & $\begin{array}{c}-0.089^{* *} \\
{[0.037]}\end{array}$ \\
\hline Credit Reputation & $\begin{array}{c}-0.092^{* * *} \\
{[0.019]}\end{array}$ & $\begin{array}{c}-0.092^{* * *} \\
{[0.019]}\end{array}$ & $\begin{array}{c}-0.093^{* * *} \\
{[0.018]}\end{array}$ & $\begin{array}{r}-0.067^{*} \\
{[0.037]}\end{array}$ & $\begin{array}{c}-0.066^{*} \\
{[0.037]}\end{array}$ & $\begin{array}{l}-0.070^{*} \\
{[0.038]}\end{array}$ \\
\hline Religious Placebo & $\begin{array}{c}0.004 \\
{[0.021]}\end{array}$ & $\begin{array}{c}0.004 \\
{[0.021]}\end{array}$ & $\begin{array}{c}0.002 \\
{[0.021]}\end{array}$ & $\begin{array}{l}0.015 \\
{[0.047]}\end{array}$ & $\begin{array}{l}0.015 \\
{[0.047]}\end{array}$ & $\begin{array}{c}0.014 \\
{[0.048]}\end{array}$ \\
\hline Control Group & $\begin{array}{c}0.006 \\
{[0.018]}\end{array}$ & $\begin{array}{c}0.011 \\
{[0.018]}\end{array}$ & $\begin{array}{c}0.010 \\
{[0.017]}\end{array}$ & $\begin{array}{c}0.011 \\
{[0.040]}\end{array}$ & $\begin{array}{c}0.013 \\
{[0.040]}\end{array}$ & $\begin{array}{c}0.017 \\
{[0.041]}\end{array}$ \\
\hline $\begin{array}{l}\text { Delinquency Rate } \\
\text { Simple Reminder Group }\end{array}$ & & 0.65 & & & & \\
\hline $\begin{array}{l}\text { Default Rate } \\
\text { Simple Reminder Group }\end{array}$ & & & & & 0.12 & \\
\hline Month fixed effects & No & Yes & Yes & No & Yes & Yes \\
\hline Controls & No & No & Yes & No & No & Yes \\
\hline Waves & & & Waves I, I & , and III & & \\
\hline $\mathrm{N}$ & & 7821 & & & 782 & \\
\hline$R^{2}$ & 0.008 & 0.017 & 0.077 & 0.021 & 0.022 & 0.057 \\
\hline
\end{tabular}

Notes: Column (1) to (6) restricts the sample to customers late in February, March, and May 2015: this is the sample of customers for which moral incentive, credit reputation, religious placebo, control group, and simple reminder have been run simultaneously, and for which information of default at 90 days from the due date is available. Using customers in the control group, we estimate a model of the probability of default by running an OLS regression of a dummy variable for whether a customer defaulted on month fixed effects and individual covariates (age, gender dummy, Muslim dummy, province dummy, income, a dummy for being in the sample in a previous month, and a dummy for having been more than 30 days past due at least once in the previous 12 months). We use the model to predict the probability of default for each customer and concentrate on the $10 \%$ of customers with the highest probability of default (High Credit Risk). Columns (1) to (3) look at delinquency and use the full sample. Columns (4) to (6) look at default and restrict the sample to customers with a high credit risk. Columns (1), (3), and (5) present OLS regression of a dummy variable for whether a customer is delinquent (did not make at least the minimum payment before the end of the grace period) on treatment group dummies. The simple reminder is the omitted group, for which we report the mean delinquency rate. Columns (2), (4), and (6) replicate and add month fixed effects and individual covariates. Columns (1) presents OLS regression of a dummy variable for whether a customer is delinquent (did not make at least the minimum payment before the end of the grace period) on treatment group dummies. The simple reminder is the omitted group, for which we report the mean delinquency rate. Column (2) replicates and adds month fixed effects. Column (3) replicates and adds individual covariates. Columns (4) presents OLS regression of a dummy variable for whether a customer defaulted at 90 days from the due date on treatment group dummies. The simple reminder is the omitted group, for which we report the mean default rate. Column (5) replicates and adds month fixed effects. Column (6) replicates and adds individual covariates. Robust standard errors in brackets. * significant at $10 \% ; * *$ significant at $5 \%$; ** significant at $1 \%$. 
Table A.11: Text Messages

\begin{tabular}{|c|c|c|}
\hline & Bahasa Indonesia & English \\
\hline Control: Basic & Bpk/Ibu Yth. Tag [name of the card] Anda th jth tempo. Utk kenya- & Dear Mr/Mrs. Your [name of the card] has reached the due date. Please \\
\hline Reminder & $\begin{array}{l}\text { manan \& keleluasaan bertransaksi, segera lakukan pemby. Jk tlh mem- } \\
\text { bayar, abaikan SMS ini.[customer service number] }\end{array}$ & $\begin{array}{l}\text { make a payment at your earliest convenience. If you have already paid, } \\
\text { ignore this text. Call [customer service number]. }\end{array}$ \\
\hline $\begin{array}{l}\text { Moral Incentive } \\
\text { [Religious] }\end{array}$ & $\begin{array}{l}\text { Bpk/Ibu Yth.Nabi SAW bersabda:"Menunda pembayaran yang di- } \\
\text { lakukan oleh orang mampu adalah suatu kezaliman"HR.Bukhari.Sgra } \\
\text { slsaikan tag Anda.[customer service number] }\end{array}$ & $\begin{array}{l}\text { Dear Mr/Mrs. The Prophet (Peace and blessings be upon Him) says: } \\
\text { "non-repayment of debts by someone who is able to repay is an injus- } \\
\text { tice" (Imam al-Bukhari). Please repay your credit card balance at your } \\
\text { earliest convenience. Call [customer service number]. }\end{array}$ \\
\hline $\begin{array}{l}\text { Moral Incentive } \\
\text { [Implicit] }\end{array}$ & $\begin{array}{l}\text { Bpk/Ibu Yth.Menunda pembayaran yang dilakukan oleh orang mampu } \\
\text { adalah suatu kezaliman.Sgra slsaikan tag Anda.[customer service num- } \\
\text { ber] }\end{array}$ & $\begin{array}{l}\text { Dear Mr/Mrs. Non-repayment of debts by someone who is able to repay } \\
\text { is an injustice. Please repay your credit card balance at your earliest } \\
\text { convenience. Call [customer service number]. }\end{array}$ \\
\hline $\begin{array}{l}\text { Moral Incentive } \\
\text { [Non-religious] }\end{array}$ & $\begin{array}{l}\text { Bpk/Ibu Yth.Menunda pembayaran yang dilakukan oleh orang mampu } \\
\text { adalah suatu ketidakadilan.Sgra slsaikan tag Anda.[customer service } \\
\text { number] }\end{array}$ & $\begin{array}{l}\text { Dear Mr/Mrs. Non-repayment of debts by someone who is able to } \\
\text { repay is an injustice [non-arabic]. Please repay your credit card balance } \\
\text { at your earliest convenience. Call [customer service number]. }\end{array}$ \\
\hline $\begin{array}{l}\text { Cash Rebate } \\
\text { Incentive }\end{array}$ & $\begin{array}{l}\text { Bpk/Ibu Yth.Bulan ini:slsaikan tag Anda utk mendapatkan hadiah } \\
\text { uang tunai sebesar } 50 \% \text { dr pembayaran minimum pada tag berikut- } \\
\text { nya.Sgra slsaikan tag Anda.[customer service number] }\end{array}$ & $\begin{array}{l}\text { Dear Mr/Mrs. This month, make your credit card payment to get a cash } \\
\text { rebate equal to } 50 \text { of your minimum payment on your next statement. } \\
\text { Please repay your credit card balance at your earliest convenience. Call } \\
\text { [customer service number]. } \\
\text { Dear Mr/Mrs. Late payments are reported monthly to Bank Indonesia }\end{array}$ \\
\hline $\begin{array}{l}\text { Credit Reputation } \\
\text { Incentive I }\end{array}$ & $\begin{array}{l}\text { Bpk/Ibu Yth.Ketrlmbtn pembyr dilaporkan k SistemInformasiDebitur } \\
\text { BI,yg semua bank berkonsltasi\&mengurangi kemampuan mendptkan } \\
\text { krdt.Sgra slsaikan tag Anda.[customer service number] }\end{array}$ & $\begin{array}{l}\text { Sistem Informasi Debitur (SID), which all banks consult. This will } \\
\text { diminish your ability to get credit in the future. Please repay your } \\
\text { credit card balance at your earliest convenience. Call [customer service } \\
\text { number]. }\end{array}$ \\
\hline $\begin{array}{l}\text { Credit Reputation } \\
\text { Incentive II }\end{array}$ & $\begin{array}{l}\text { Bpk/Ibu Yth.Ketrlmbtn pembyr dilaporkan k SistemInformasiDeb- } \\
\text { itur BI,yg semua bank dapat berkonsultasi.Sgra slsaikan tag } \\
\text { Anda.[customer service number] }\end{array}$ & $\begin{array}{l}\text { Dear Mr/Mrs. Late payments are reported monthly to Bank Indonesia } \\
\text { Sistem Informasi Debitur (SID), which all banks can consult. Please } \\
\text { repay your credit card balance at your earliest convenience. Call [cus- } \\
\text { tomer service number]. }\end{array}$ \\
\hline $\begin{array}{l}\text { Placebo: Simple } \\
\text { Reminder }\end{array}$ & $\begin{array}{l}\text { Bpk/Ibu Yth.Tagihan [name of the card] Anda jatuh tempo pada } \\
\text { tanggal [due date] dan pmbayarn belum diterima.Sgra slsaikan tag } \\
\text { Anda. [customer service number] }\end{array}$ & $\begin{array}{l}\text { Dear Mr/Mrs. The due date of your [name of the card] bill was on [due } \\
\text { date] and your payment has not been received yet. Please repay your } \\
\text { credit credit card balance at your earliest convenience. Call [customer } \\
\text { service number]. }\end{array}$ \\
\hline $\begin{array}{l}\text { Placebo: Religious } \\
\text { Message }\end{array}$ & $\begin{array}{l}\text { Bpk/Ibu Yth.Nabi SAW bersabda:" Jika Allah menginginkan yg } \\
\text { terbaik buat umatnya,IA melimpahkan padanya pengetahuan } \\
\text { Kitab" HR.Bukhari.Sgra slsaikan tag Anda.[customer service number] }\end{array}$ & $\begin{array}{l}\text { Dear Mr/Mrs. The Prophet (Peace and blessings be upon Him) says: } \\
\text { When Allah wishes good for someone, He bestows upon him the under- } \\
\text { standing of the Book (Imam al-Bukhari). Please repay your credit card } \\
\text { balance at your earliest convenience. Call [customer service number]. }\end{array}$ \\
\hline
\end{tabular}




\section{A Survey Instruments}

\section{A.1 Religion and Religiosity}

Assalamu'alaikum Sir/Madam,

May I please speak to Mr./Mrs. [cardholder name]. I am calling from [bank name] and would like to ask a few questions to improve the services we offer with [name of the credit card]. This will take less than 5 minutes. Are you willing to participate?

1. Please rank the following in terms of importance in your life, from 1 (most important)

to 4 (least important)

- Family

- Work

- Friends

- Religion

2. How important is religion in your life?

Not important at all [1] [2] [3] [4] [5] Extremely important

3. To you personally, how important is it to behave morally? Not important at all [1] [2] [3] [4] [5] Extremely important

4. To you personally, how important are the rules of Islam and Sharia law? Not important at all [1] [2] [3] [4] [5] Extremely important

5. Who do you think might have said the following phrase:

"Non repayment of debt by someone who can afford is an injustice"?

- Islamic Council

- Prophet Mohammad (peace and blessings be upon Him)

- Director of [bank name]

- Director of Bank Indonesia

- Don’t Know

Thank you so much for your participation in this survey designed to improve our service. Have a nice day. Wassalamu'alaikum warahmatullahi wabarakatuh! 


\section{A.2 Enforcement and Disutility from the Message [Control]}

Assalamu'alaikum Sir/Madam,

May I please speak to Mr./Mrs. [cardholder name]. I am calling from [bank name] and would like to ask a few questions to improve the services we offer with [name of the credit card]. This will take less than 5 minutes. Are you willing to participate?

1. How committed do you think [name of bank] is to collect debts from delinquent customers on a scale from 1 (not very committed) to 5 (very committed)?

2. [Name of bank] is sending reminder messages to its customers to help them make their payments on time. You received one of these messages last week. Would you like to receive the same message in the future? Yes [ ] No [ ]

3. What do you think would be the consequences of being reported to the Bank Indonesia Sistem Informasi Debitur credit registry for non-repayment of debts?

- Will not be able to open new deposit accounts Yes [ ] No []

- Will not be able to get new credit from [bank name] Yes [ ] No [ ]

- Will not be able to get new credit from any other bank Yes [] No []

- Will have to go on trial/appear in front of a judge Yes [ ] No [ ]

Thank you so much for your participation in this survey designed to improve our service. Have a nice day. Wassalamu'alaikum warahmatullahi wabarakatuh! 


\section{A.3 Enforcement and Disutility from the Message [Treatment]}

Assalamu'alaikum Sir/Madam,

May I please speak to Mr./Mrs. [cardholder name]. I am calling from [bank name] and would like to ask a few questions to improve the services we offer with [name of the credit card]. This will take less than 5 minutes. Are you willing to participate?

1. How committed do you think [name of bank] is to collect debts from delinquent customers on a scale from 1 (not very committed) to 5 (very committed)?

2. [Name of bank] is sending reminder messages to its customers to help them make their payments on time. You received one of these messages last week. Would you like to receive the same message in the future? Yes [ ] No [ ]

3. We sent this SMS to some of our customers being late on their credit card repayment: "Dear Mr/Mrs. Late payments are reported monthly to Bank Indonesia Sistem Informasi Debitur, which all banks consult. This will diminish your ability to get credit in the future. Please repay your card balance at your earliest convenience. Call [customer service number]." What do you think would be the consequences if you get reported to the Bank Indonesia Sistem Informasi Debitur credit registry for missed payments?

- Will not be able to open new deposit accounts Yes [ ] No []

- Will not be able to get new credit from [bank name] Yes [ ] No []

- Will not be able to get new credit from any other bank Yes [] No []

- Will have to go on trial/appear in front of a judge Yes [ ] No []

Thank you so much for your participation in this survey designed to improve our service. Have a nice day. Wassalamu'alaikum warahmatullahi wabarakatuh! 


\section{A.4 Preferences for Delayed Cash Rebate}

Assalamu'alaikum Sir/Madam,

May I please speak to Mr./Mrs. [cardholder name]. I am calling from [bank name] and would like to ask a few questions regarding cash rebates on your [name of the credit card]. Do you have a couple of minutes to answer?

1. We want to understand how much value customers give to cash rebates on their [name of the credit card], and whether they prefer cash rebates or deposits on their checking account. Among these two, what would you prefer? [if (b) then stop]

(a) 100,000 Rp as a deposit on your checking account today, or

(b) 100,000 Rp as a cash rebate on your next credit card statement?

2. How about: [if (b) then stop]

(a) 95,000 Rp as a deposit on your checking account today, or

(b) 100,000 $\mathrm{Rp}$ as a cash rebate on your next credit card statement?

3. How about: [if (b) then stop]

(a) 90,000 Rp as a deposit on your checking account today, or

(b) $100,000 \mathrm{Rp}$ as a cash rebate on your next credit card statement?

4. How about: [if (b) then stop]

(a) $85,000 \mathrm{Rp}$ as a deposit on your checking account today, or

(b) $100,000 \mathrm{Rp}$ as a cash rebate on your next credit card statement?

[Continue asking until they say (b): ask about 80,000, 75,000, 70,000, etc.]

Thank you so much for your participation in this survey.

Have a nice day. Wassalamu'alaikum warahmatullahi wabarakatuh! 


\section{B Theoretical Results}

\section{B.1 Contracting with Moral Hazard}

To illustrate the implications of introducing a moral cost of debt non-repayment in moral hazard models of credit, we consider the canonical corporate finance model described, for example, in Tirole (Theory of Corporate Finance, 2006).

A risk-neutral borrower has a project, which requires a fixed investment $I$ and has assets $A<I$. The borrower can either invest money in the project or use it for consumption. But, since the project requires a fixed investment of $I>A$, she needs to borrow $I-A$ from a lender. There is a large number of risk-neutral lenders.

If undertaken, the project either succeeds or fails. A project that succeeds generates a verifiable income of $R>0$. A project that fails generates no income. The success of the project depends, in part, on the borrower's effort. If the borrower exerts effort, the project succeeds with probability $p_{H}$. If the borrower shirks, it succeeds with probability $p_{L}$.

To simplify notation, we assume that there is no discounting. Since there is a large number of lenders, the borrower has all bargaining power, so that each (risk-neutral) lender would accept to provide financing as long as the expected return is at least zero. The borrower is protected by limited liability, so her income cannot fall below zero.

Because of limited liability, both parties will receive zero in case of failure. In case of success, they share the profit $R$, with $R_{b}$ going to the borrower and $R_{l}$ going to the seller, giving the lender a profit of

$$
R_{l}-(I-A)
$$

in case of success, and $-(I-A)$ in case of failure, and giving the borrower a profit of

$$
R_{b}-A
$$

in case of success and $-A$ in case of failure. The zero-profits constraint for lenders is then:

$$
p_{H} R_{l}=I-A
$$

assuming that it is only efficient to start the project if the borrower works hard:

$$
p_{H} R-I>0>p_{L} R-I+B .
$$

The incentive compatibility constraint that ensures that the borrower works hard is

$$
p_{H} R_{b} \geq p_{L} R_{b}+B \therefore R_{b} \geq \frac{B}{\Delta p}
$$


where $B$ is the private benefit from shirking and $\Delta p \equiv p_{H}-p_{L}$ is the effect of effort on the probability of success. Since $R_{l}=R-R_{b}$, incentive compatibility implies that the highest share of the project $R_{l}$ that can be pledged to the lenders without jeopardizing the borrower's incentives is

$$
R-\frac{B}{\Delta p}
$$

If the borrower had to repay a share $R_{l}$ greater than this amount, she would not have an incentive to work hard, which would be unprofitable.

Since lenders must break even in order to agree to finance the project - equation (B.1) -, the project can be undertaken if and only if the maximum pledgeable income (B.2) allows the lender to break even:

$$
p_{H}\left(R-\frac{B}{\Delta p}\right) \geq I-A .
$$

In technical terms, this condition ensures that high effort is implementable. That is, the project, which has positive NPV, can only be undertaken if the borrower has at least $\bar{A}$ assets, where

$$
\bar{A} \equiv I-p_{H}\left(R-\frac{B}{\Delta p}\right)
$$

Whenever $A<\bar{A}$, the positive-NPV project cannot funded because the borrower does not have enough pledgeable income, which is inefficient.

Now, suppose the borrower has a utility cost $\kappa \geq 0$ from defaulting, meaning that her utility if the project fails is now $-A-\kappa$. The incentive compatibility constraint is now

$$
p_{H} R_{b}-\left(1-p_{H}\right) \kappa \geq p_{L} R_{b}-\left(1-p_{L}\right) \kappa+B
$$

which can be rearranged as

$$
R_{b} \geq \frac{B}{\Delta p}-\kappa
$$

Thus, the borrower's pledgeable income becomes

$$
R-\frac{B}{\Delta p}+\kappa
$$

meaning that a higher utility cost of defaulting increases the borrower's pledgeable income, reducing the range of parameters under which efficient projects are not undertaken. Therefore, holding all other parameters constant, a higher moral cost of defaulting increases the share of projects that are funded and the efficiency of the economy. 


\section{B.2 Contracting with Adverse Selection}

Now, we illustrate the implications of introducing a moral cost of default in adverse selection models of debt. Consider a borrower who has no initial funds and wants to finance a project that costs $I>0$. As before, the project yields $R$ if it succeeds and 0 if it fails. The borrower and the lenders are risk neutral and they are both protected by limited liability. For simplicity, we normalize the interest rate to 0 .

There are two types of borrowers. A good type has a probability of success $p$, and a bad borrower has a probability of success $q$, where $p>q$, meaning that a good type has a better chance of succeeding than a bad type. To ensure that the model is non-trivial, we assume that it is efficient to finance the good type but not the bad type:

$$
p R>I>q R .
$$

If this were not the case, adverse selection would not be "binding" in the sense that all types would always get funded (or it would be efficient not to fund anyone).

The borrower's type is her private information. Lenders accept to finance a project as long as they get a non-negative rate of return. They have prior probability $\alpha$ on the borrower being a good and $1-\alpha$ on the borrower being a bad type, so that $m \equiv \alpha p+(1-\alpha) q$ is their prior probability of success.

Because lenders have limited liability, they cannot offer financing contracts that pay positive amounts in case of failure. Therefore, there is no loss of generality in considering a "pooling contract" that gives the borrower a compensation of $R_{b} \leq R$ in case of success and 0 in case of failure. This contract can be interpreted as a debt contract with face value $R_{l}{ }^{56}$ Because borrowers have limited liability, this compensation cannot be negative, $R_{b} \geq 0$, which means that both types would prefer to be funded than remaining unfunded and getting a zero payoff.

An investor's profit from funding both types equals

$$
m\left(R-R_{b}\right)-I=[\alpha p+(1-\alpha) q]\left(R-R_{b}\right)-I=0
$$

which means that the borrower's compensation in case of success is

$$
R_{b}=R-\frac{I}{\alpha p+(1-\alpha) q}
$$

To verify that such a contract is an equilibrium, we need to verify that it satisfies limited liability. Since $R_{b}<R$, it satisfies limited liabitliy for the lender. It satisfies limited liability for the borrower

\footnotetext{
${ }^{56}$ Although debt contracts are not very meaningful with binary outputs, but Nachman and Noe (RFS 1994) and DeMarzo and Duffie (Econometrica 1999) show that, under some conditions on the distribution of types, the optimal contract is still a debt contract even with a continuum of outputs.
} 
if and only if the borrower's compensation derived in (B.3) is positive:

$$
R-\frac{I}{\alpha p+(1-\alpha) q} \geq 0 \Longleftrightarrow \alpha \geq \frac{q R-I}{R(q-p)} .
$$

If this condition fails, no one gets funded (the market "breaks down"). To conclude, if there are sufficiently many good types, everyone gets funding. Otherwise, no one gets funding.

Now, suppose the borrower has a utility $\operatorname{cost} \kappa \geq 0$ from defaulting. Then, the bad type's expected payoff is

$$
q R_{b}-(1-q) \kappa
$$

whereas the good type's expected payoff is

$$
p R_{b}-(1-p) \kappa
$$

We claim that, for intermediate values of $\kappa$, the equilibrim contract finances good types only, which is the first-best allocation that is never feasible when there are no costs from defaulting. For the contract to finance only good types, the following incentive compatibility constraints must be satisfied

$$
p R_{b}-(1-p) \kappa \geq 0 \geq q R_{b}-(1-q) \kappa,
$$

where $R_{b}$ is determined by the zero-profits constraints (using the probability distribution of good types):

$$
R_{b}=R-\frac{I}{p}
$$

Importantly, notice that a utility cost of not repaying the debt $\kappa$ disproportionately hurts bad types, since they are more likely to default. These two conditions can be rewritten as:

$$
\frac{p}{1-p}\left(R-\frac{I}{p}\right) \geq \kappa \geq \frac{q}{1-q}\left(R-\frac{I}{p}\right)
$$

That is, for intermediate utility costs of debt non-repayment, the first-best allocation can be implemented. Intuitively, the moral cost of non-repayment goes in the opposite direction of the "death spiral" problem in lemons markets that causes markets to unravel. A death spiral may occur because a good borrower is more likely to succeed and, therefore, have to repay a loan. A moral cost of non-repayment, on the other hand, disproportionately hurts a bad borrower, who is more likely to be unable to repay.

In addition, when the moral cost of debt non-repayment is not observed by the lenders, the model typically has multiple equilibria. Intuitively, the interest rate charged by the lender depends on whether repayment is determined mostly by the quality of the project or by the moral cost of failing to repay the debt. We can have equilibria in which interest rates are low because default is 
mostly affected by morality considerations, so that many borrowers with good projects are funded, and other equilibria in which interest rates are high because default is mostly affected by the quality of the project, and mostly borrowers with bad projects are funded.

Formally, suppose that the cost of debt non-repayment is drawn from a uniform distribution in $[0, K]$, so that participation is random in the sense of Rochet and Stole (Restud 2002). As usual, this can be interpreted either as a situation with a single borrower with private information about her moral cost of debt non-repayment or as a situation in which there is a population of borrowers with heterogeneous moral costs of debt non-repayment. Now, the decision to accept financing is characterized by thresholds for the moral cost of default: individuals with moral costs below such threshold will be financed. The participation threshold for borrowers with good projects is

$$
\frac{p}{1-p} R_{b}=\bar{\kappa}_{H}
$$

and the participation threshold for borrowers with bad projects is

$$
\frac{q}{1-q} R_{b}=\bar{\kappa}_{L}
$$

For simplicity, we will take $K$ to be large enough so that these cutoffs are interior in equilibrium. Notice that because a bad borrower is more likely to fail $(p>q)$, her participation threshold is lower than the one of a good borrower $\left(\bar{\kappa}_{L}<\bar{\kappa}_{H}\right)$. That is, as before, a disutility from not repaying the debt disproportionately affects bad borrowers.

The lender's zero-profits condition is:

$$
\frac{1}{K}\left[\alpha \frac{p^{2}}{1-p}+(1-\alpha) \frac{q^{2}}{1-q}\right] R_{b}\left(R-R_{b}\right)-I=0 .
$$

There are (generically) two possibilities:

- If $R<2 \sqrt{\frac{I K}{\frac{\alpha p^{2}}{1-p}+\frac{(1-\alpha) q^{2}}{1-q}}}$, there is no equilibrium with positive financing (the market breaks down);

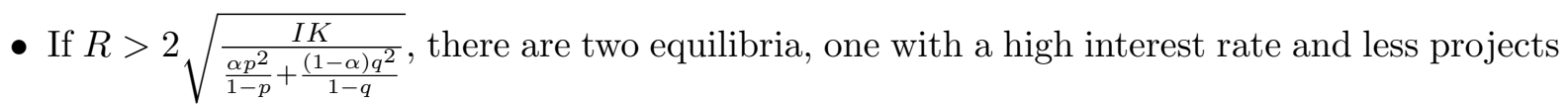
being financed:

$$
R_{b}^{*}=\frac{R+\sqrt{R^{2}-\frac{4 I K}{\frac{\alpha p^{2}}{1-p}+\frac{(1-\alpha) q^{2}}{1-q}}}}{2} \in\left(\frac{R}{2}, R\right)
$$


and one with a low interest rate and more projects being financed:

$$
R_{b}^{*}=\frac{R-\sqrt{R^{2}-\frac{4 I K}{\frac{\alpha p^{2}}{1-p}+\frac{(1-\alpha) q^{2}}{1-q}}}}{2} \in\left(0, \frac{R}{2}\right) \text {, }
$$

Therefore, the existence of heterogeneous utility costs of debt non-repayment endogenously introduces multiplicity of equilibrium: in one of them, lenders fund many good projects and participation is disproportionately affected by the moral cost of debt non-repayment, and, in the other equilibrium, lenders fund many bad projects and participation is disproportionately affected by the quality of the project.

\section{B.3 General Equilibrium with Incomplete Markets}

We now discuss the implications of our results based on a literature that studies general equilibrium models with incomplete markets. For example, consider the canonical model of Dubey et al., 2005, which assumes that individuals experience an exogenous disutility when they default. While this disutility from default is often interpreted as a reduced-form of reputation considerations (which are outside of the model), they may also be interpreted as a moral cost from defaulting.

Interestingly, in models with incomplete markets, increasing the moral cost of debt non-repayment has ambiguous effects on efficiency, with the highest welfare typically associated with some intermediate cost. When individuals have no cost from debt non-repayment, no one would be willing to lend as borrowers have no incentive to repay. On the other hand, if their cost from failing to repay their debt is high enough and their endowment is low enough in some state of the world, borrowers would choose not to borrow, since they would not want to risk being unable to repay. Typically, the most efficient outcome is obtained when the moral cost of debt non-repayment is at an intermediate level. 